\title{
Development of an axial chirality switch
}

\author{
Stefan Reichert and Bernhard Breit* \\ Institut für Organische Chemie und Biochemie, Albert-Ludwigs-Universität Freiburg i. Br., Germany
}

\section{Supplementary Material}

(30 pages)

\section{General}

All reactions were carried out in dried glassware under an argon atmosphere 5.0 (SüdwestGas). Air and moisture sensitive liquids and solutions were transferred via syringe. All reagents were obtained commercially unless otherwise noted. Copper(I)thiophenecarboxylate $(\mathrm{CuTC})^{[13]}$ was synthesized according to a literature procedure. All solvents were dried and distilled by standard procedures. Organic solutions were concentrated under reduced pressure by rotary evaporation. Chromatographic purification of products was accomplished using flash chromatography on a Merck silica gel Si 60 ${ }^{\circledR}$ (200-400 mesh).

Nuclear magnetic resonance spectra were acquired on a Varian Mercury spectrometer (300 MHz and $75 \mathrm{MHz}$ for ${ }^{1} \mathrm{H}$ and ${ }^{13} \mathrm{C}$ respectively), on a Bruker AMX 400 (400 MHz, 235

$\mathrm{MHz}$ and $100 \mathrm{MHz}$ for ${ }^{1} \mathrm{H},{ }^{19} \mathrm{~F}$ and ${ }^{13} \mathrm{C}$ respectively) and on a Bruker DRX $500(500 \mathrm{MHz}$ and $125 \mathrm{MHz}$ for ${ }^{1} \mathrm{H}$ and ${ }^{13} \mathrm{C}$ respectively) and are referenced according to residual protio solvent signals. Data for ${ }^{1} \mathrm{H}-\mathrm{NMR}$ are recorded as follows: chemical shift ( $\delta$ in $\left.\mathrm{ppm}\right)$, multiplicity (s, singlet; br s, broad singlet; d, doublet; t, triplet; q, quartet; m, multiplet; $\mathrm{p}$, pseudo), coupling constant $(\mathrm{Hz})$, integration. Data for ${ }^{13} \mathrm{C}-\mathrm{NMR}$ are reported in terms of chemical shift ( $\delta$ in ppm), multiplicity (if not a singlet), coupling constant (Hz).

High-resolution mass spectra were obtained on a Finnigan MAT 8200 instrument. Elementary analysis was performed on an elementar vario (Fa. Elementar Analysensysteme GmbH).

Preparative HPLC separations were performed on a Fa. Knauer K-1800 (pump), D-7400 (detector) instrument. Analytical HPLC was performed on a Dionex P580 (pump) UVD170S (detector) instrument using a Merck SI60, $5 \mu \mathrm{m}$ column.

$\mathrm{CD}$ measurements were done on a Fa. Jasco spectropolarimeter J-810. 


\section{Experimental Section}

\section{$N$-(3-methoxybenzylidene)cyclohexanamine 11}

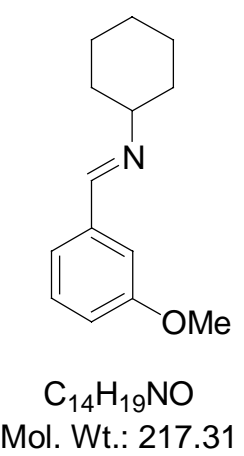

To a solution of 3-methoxybenzaldehyde $7(6.10 \mathrm{ml}, 6.83 \mathrm{~g}, 50.2 \mathrm{mmol})$ in $\mathrm{CH}_{2} \mathrm{Cl}_{2}(50 \mathrm{ml})$ were added $\mathrm{MgSO}_{4}(5.00 \mathrm{~g})$ and cyclohexanamine $(8.60 \mathrm{ml}, 7.48 \mathrm{~g}, 75.4 \mathrm{mmol}, 1.5 \mathrm{eq}$.). The resulting suspension was stirred for $2 \mathrm{~h}$ at room temperature, the $\mathrm{MgSO}_{4}$ was filtered off, rinsed with $\mathrm{CH}_{2} \mathrm{Cl}_{2}(80 \mathrm{ml})$ and the solvent was removed under reduced pressure. The residue was purified by bulb-to-bulb distillation at $149{ }^{\circ} \mathrm{C}(0.9 \mathrm{mbar})$ to yield the title compound 11 (10.74 g, $49.4 \mathrm{mmol}, 98 \%)$ as a yellow liquid.

${ }^{1}$ H-NMR $\left(400 \mathrm{MHz}, \mathrm{CDCl}_{3}\right): \delta 1.27\left(\mathrm{~m}_{\mathrm{c}}, 3 \mathrm{H}\right), 1.56\left(\mathrm{~m}_{\mathrm{c}}, 1 \mathrm{H}\right), 1.76\left(\mathrm{~m}_{\mathrm{c}}, 6 \mathrm{H}\right), 3.06\left(\mathrm{~m}_{\mathrm{c}}, 1 \mathrm{H}\right)$, 3.29 (s, 3H), $6.86(\mathrm{ddd}, J=8.2,2.6,1.0 \mathrm{~Hz}, 1 \mathrm{H}), 7.10$ (pt, $J=7.9 \mathrm{~Hz}, 1 \mathrm{H}), 7.29\left(\mathrm{~m}_{\mathrm{c}}, 1 \mathrm{H}\right)$, $7.62(\mathrm{dd}, J=2.6,1.4 \mathrm{~Hz}, 1 \mathrm{H}), 8.07(\mathrm{~s}, 1 \mathrm{H}) ;{ }^{13} \mathrm{C}-\mathrm{NMR}\left(100 \mathrm{MHz}, \mathrm{CDCl}_{3}\right): \delta 25.0(2 \mathrm{C}), 26.1$, 34.9 (2C), 54.7, 70.1, 111.9, 117.5, 121.9, 129.6, 138.9, 158.1, 160.5.

\section{$N$-(2-iodo-3-methoxybenzylidene)cyclohexanamine 8}

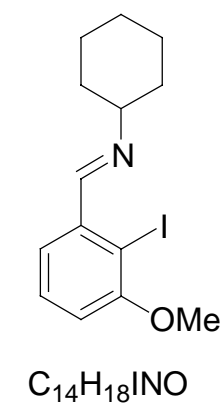

Mol. Wt.: 343.20 
To a solution of tetramethylpiperidine $(9.70 \mathrm{ml}, 8.05 \mathrm{~g}, 57.0 \mathrm{mmol}, 2.3 \mathrm{eq}$.) in THF was added at $-15^{\circ} \mathrm{C} n$-BuLi $(37.5 \mathrm{ml}, 57.0 \mathrm{mmol}, 2.3$ eq., $1.52 \mathrm{M}$ in hexane) over $30 \mathrm{~min}$. The solution was stirred for an additional $30 \mathrm{~min}$ at $-15{ }^{\circ} \mathrm{C}$ and then a solution of $\mathrm{N}$-(3methoxybenzylidene)cyclohexanamine $11(5.43 \mathrm{~g}, 25.0 \mathrm{mmol})$ in THF (10 ml) was added over $15 \mathrm{~min}$. The reaction mixture was stirred for an additional $1.5 \mathrm{~h}$ at $-15^{\circ} \mathrm{C}$, cooled down to $-78{ }^{\circ} \mathrm{C}$ and a solution of iodine $(15.9 \mathrm{~g}, 62.5 \mathrm{mmol}, 2.5 \mathrm{eq}$.) in THF (25 ml) was added. The reaction mixture was allowed to warm to room temperature over $2 \mathrm{~h}$ and was added to halfsat. aqueous $\mathrm{Na}_{2} \mathrm{~S}_{2} \mathrm{O}_{3}(250 \mathrm{ml})$. The layers were separated and the aqueous phase was extracted with $\mathrm{CH}_{2} \mathrm{Cl}_{2}(3 \times 80 \mathrm{ml})$. The combined organic layers were washed with sat. aqueous $\mathrm{NH}_{4} \mathrm{Cl}(2 \times 40 \mathrm{ml})$ and dried $\left(\mathrm{MgSO}_{4}\right)$. After concentration the residue was filtrated over neutral alumina with EtOAc. Concentration gave the title compound 8 (8.44 $\mathrm{g}$, $24.6 \mathrm{mmol}, 98 \%$ ) as a yellow solid, which was used without further purification in the next step.

${ }^{1}$ H-NMR $\left(500 \mathrm{MHz}, \mathrm{C}_{6} \mathrm{D}_{6}\right): \delta 1.20\left(\mathrm{~m}_{\mathrm{c}}, 3 \mathrm{H}\right), 1.51\left(\mathrm{~m}_{\mathrm{c}}, 1 \mathrm{H}\right), 1.70\left(\mathrm{~m}_{\mathrm{c}}, 6 \mathrm{H}\right), 3.17(\mathrm{~s}, 3 \mathrm{H}), 3.20$ $\left(\mathrm{m}_{\mathrm{c}}, 1 \mathrm{H}\right), 6.23(\mathrm{dd}, J=8.0,1.4 \mathrm{~Hz}, 1 \mathrm{H}), 6.92$ (pt, $\left.J=8.0 \mathrm{~Hz}, 1 \mathrm{H}\right), 7.97$ (dd, $J=7.8,1.4 \mathrm{~Hz}$, $1 \mathrm{H}), 8.81(\mathrm{~s}, 1 \mathrm{H}) ;{ }^{13} \mathrm{C}-\mathbf{N M R}\left(125 \mathrm{MHz}, \mathrm{C}_{6} \mathrm{D}_{6}\right): \delta 24.8(2 \mathrm{C}), 26.0,34.8(2 \mathrm{C}), 55.9,69.6,93.6$, 112.3, 121.9, 129.0, 139.7, 158.3, 162.1; CHN: calcd. C: 48.99, H: 5.29, N: 4.08 found C: $49.02 \mathrm{H}: 5.44 \mathrm{~N}: 4.06 ; \mathbf{m p}: 104-106{ }^{\circ} \mathrm{C}$.

\section{rac-6,6'-Dimethoxybiphenyl-2,2'-dicarbaldehyde 9}

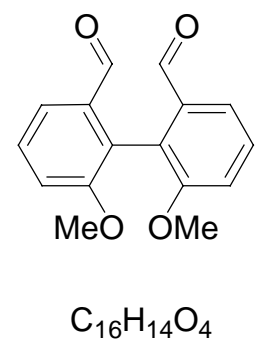

Mol. Wt.: 270.28

To a solution of $N$-(2-iodo-3-methoxybenzylidene)cyclohexanamine 8 (8.44 g, $24.6 \mathrm{mmol})$ in NMP (50 ml) was added copper(I)-thiophenecarboxylate $(11.7 \mathrm{~g}, 61.5 \mathrm{mmol}, 2.5$ eq.). The resulting suspension was stirred for $24 \mathrm{~h}$ at room temperature with exclusion of light. 
Addition of conc. aqueous $\mathrm{NH}_{3}(250 \mathrm{ml})$ resulted in a blue solution, which was extracted with EtOAc $(4 \times 100 \mathrm{ml})$. The combined organic layers were washed with $\mathrm{NH}_{3}(3 \times 50 \mathrm{ml}, 12.5 \%)$, brine $(2 \times 50 \mathrm{ml})$ and concentrated. The residue was dissolved in $\mathrm{CH}_{2} \mathrm{Cl}_{2}(50 \mathrm{ml}), \mathrm{HCl}(35 \mathrm{ml}$, $6 \mathrm{M}$ ) was added and the mixture was stirred at room temperature for $2 \mathrm{~h}$. The layers were separated and the aqueous phase was extracted with $\mathrm{CH}_{2} \mathrm{Cl}_{2}(3 \times 40 \mathrm{ml})$. The combined organic layers were washed with $\mathrm{HCl}(2 \times 20 \mathrm{ml}, 1 \mathrm{M})$, sat. aqueous $\mathrm{NaHCO}_{3}(40 \mathrm{ml})$, brine $(40 \mathrm{ml})$, dried $\left(\mathrm{MgSO}_{4}\right)$ and concentrated. The residue was purified by flash chromatography (Cy/EtOAc 5:1 to 1:1) to furnish the title compound 9 (2.86 g, $10.6 \mathrm{mmol}, 86 \%)$ as a white solid.

${ }^{1}$ H-NMR (500 MHz, $\mathrm{CDCl}_{3}$ ): $\delta 3.73(\mathrm{~s}, 6 \mathrm{H}), 7.22(\mathrm{dd}, J=8.2,0.9 \mathrm{~Hz}, 2 \mathrm{H}), 7.54(\mathrm{pt}, J=8.0$ $\mathrm{Hz}, 2 \mathrm{H}), 7.67(\mathrm{dd}, J=7.8,1.1 \mathrm{~Hz}, 2 \mathrm{H}), 9.66(\mathrm{~s}, 2 \mathrm{H}) ;{ }^{13} \mathbf{C}-\mathbf{N M R}\left(125 \mathrm{MHz}, \mathrm{CDCl}_{3}\right): \delta 56.1$ (2C), 116.0 (2C), 119.8 (2C), 125.5 (2C), 129.9 (2C), 135.9 (2C), 157.3 (2C), 191.7 (2C); mp: $113-114^{\circ} \mathrm{C}$.

\section{rac-4,5-Dimethoxy-9,10-dihydrophenanthrene-9,10-diol 2}

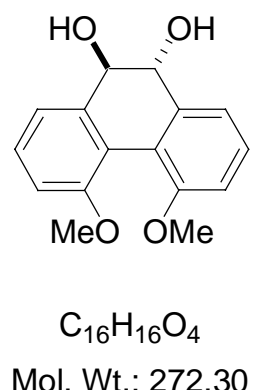

A mixture of Samarium (250 mg, $1.66 \mathrm{mmol}, 3$ eq.) and diiodoethane (457 mg, $1.62 \mathrm{mmol}$, 2.9 eq.) were suspended in THF (16.5 ml) and stirred at room temperature under exclusion of light for $2 \mathrm{~h}$. During this time the mixture was irradiated 4 times in an ultrasonic bath, each time for $5 \mathrm{~min}$. The resulting blue solution was then cooled to $0^{\circ} \mathrm{C}$ and a solution of $\mathrm{rac}-6,6^{\prime}-$ dimethoxybiphenyl-2,2'dicarbaldehyde 9 (150 mg, $0.56 \mathrm{mmol})$ in THF $(4.5 \mathrm{ml})$ was added dropwise over $15 \mathrm{~min}$. The reaction mixture was stirred until complete consumption of the starting material and then allowed to warm to room temperature. After quenching with $\mathrm{HCl}$ $(50 \mathrm{ml}, 1 \mathrm{M})$ the layers were separated and the aqueous layer was extracted with EtOAc $(4 \times 15 \mathrm{ml})$. The combined organic layers were washed with sat. aqueous $\mathrm{NaHCO}_{3}(15 \mathrm{ml})$, sat. 
aqueous $\mathrm{NaS}_{2} \mathrm{O}_{3}(15 \mathrm{ml})$, brine $(15 \mathrm{ml})$ and dried $\left(\mathrm{MgSO}_{4}\right)$. After concentration, the residue was purified by flash chromatography (Cy/EtOAc 3:1 to 1:1) to furnish the title compound 2 (134 $\mathrm{mg}, 0.49 \mathrm{mmol}, 88 \%)$ as a white solid.

${ }^{1}$ H-NMR (500 MHz, CDCl $)$ ): $\delta 3.89$ (s, 6H), 4.42 (br s, 2H), 6.99 (d, J=8.2 Hz, 2H), 7.24 $\left(\mathrm{m}_{\mathrm{c}}, 2 \mathrm{H}\right), 7.34\left(\mathrm{~m}_{\mathrm{c}}, 2 \mathrm{H}\right) \mathrm{OH}$ not detected; ${ }^{13} \mathrm{C}-\mathrm{NMR}\left(125 \mathrm{MHz}, \mathrm{CDCl}_{3}\right): \delta 55.9(2 \mathrm{C}), 74.2$ (2C), 111.4 (2C), 115.4 (2C), 119.0 (2C), 128.9 (2C), 139.0 (2C), 156.2 (2C); HRMS: calcd. 272.1049 found 272.1048 ; $\mathbf{m p}: 143-145{ }^{\circ} \mathrm{C}$.

rac-3-Bromo-6,6'-dimethoxybiphenyl-2,2'-dicarbaldehyde 10

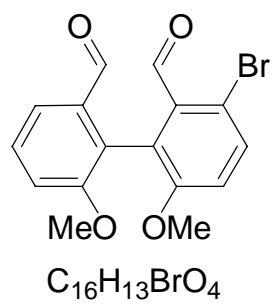

Mol. Wt.: 349.18

To a solution of rac-6,6'-dimethoxybiphenyl-2,2'dicarbaldehyde 9 (676 mg, $2.48 \mathrm{mmol}$ ) in DMF (15 ml) was added a solution of $N$-bromosuccinimide (534 mg, $3.00 \mathrm{mmol}, 1.2$ eq.) in DMF $(10 \mathrm{ml})$ over $5 \mathrm{~h}$. The resulting reaction mixture was stirred at room temperature for $8 \mathrm{~h}$, diluted with $\mathrm{H}_{2} \mathrm{O}(180 \mathrm{ml})$ and extracted with $\mathrm{MTBE}(3 \times 50 \mathrm{ml})$. The combined organic layers were dried $\left(\mathrm{MgSO}_{4}\right)$ and concentrated. The residue was purified by flash chromatography ( Tol/ $\mathrm{CH}_{2} \mathrm{Cl}_{2} 2: 1$ to 1:1) and furnished the title compound $10(384 \mathrm{mg}, 1.10 \mathrm{mmol}, 44 \%)$ as a yellow solid. Additionally the starting material 9 (322 mg, $1.19 \mathrm{mmol}, 48 \%)$ could be reisolated as a white solid.

${ }^{1}$ H-NMR (500 MHz, $\mathrm{CDCl}_{3}$ ): $\delta 3.69$ (s, 3H), 3.72 (s, 3H), $7.03(\mathrm{~d}, J=8.8 \mathrm{~Hz}, 1 \mathrm{H}), 7.17$ (dd, $J=8.2,1.1 \mathrm{~Hz}, 1 \mathrm{H}), 7.50(\mathrm{pt}, J=8.0 \mathrm{~Hz}, 1 \mathrm{H}), 7.62(\mathrm{dd}, J=7.7,1.1 \mathrm{~Hz}, 1 \mathrm{H}), 7.68(\mathrm{~d}, J=8.8$ $\mathrm{Hz}, 1 \mathrm{H}), 9.66(\mathrm{~d}, J=0.8 \mathrm{~Hz}, 1 \mathrm{H}), 10.06(\mathrm{~s}, 1 \mathrm{H}) ;{ }^{13} \mathbf{C}-\mathbf{N M R}\left(125 \mathrm{MHz}, \mathrm{CDCl}_{3}\right): \delta 56.1,56.3$, $115.4,116.1,116.11,120.4,125.8,126.6,129.5,134.3,134.7,135.5,156.4,156.9,191.6$, 191.8; CH: calcd. C: 55.04, H: 3.75 found C: 55.28, H: 3.64; mp: $127-128{ }^{\circ} \mathrm{C}$. 


\section{rac-1-Bromo-4,5-dimethoxy-9,10-dihydrophenanthrene-9,10-diol 5}

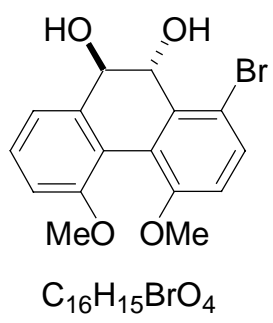

Mol. Wt: 351.19

To a solution of $\mathrm{SmI}_{2}(7.20 \mathrm{ml}, 0.72 \mathrm{mmol}, 2.50$ eq., $0.1 \mathrm{M}$ in THF $)$ at $0{ }^{\circ} \mathrm{C}$ was added a solution of rac-3-bromo-6,6'-dimethoxybiphenyl-2,2'-dicarbaldehyde $\mathbf{1 0}$ (100 mg, $0.29 \mathrm{mmol})$ in THF $(3.0 \mathrm{ml})$ over $15 \mathrm{~min}$. The reaction mixture was stirred for $25 \mathrm{~min}$ at $0{ }^{\circ} \mathrm{C}$, allowed to warm to room temperature and quenched with $\mathrm{HCl}(10 \mathrm{ml}, 1 \mathrm{M})$. The layers were separated and the aqueous layer was extracted with $\mathrm{CH}_{2} \mathrm{Cl}_{2}(4 \times 20 \mathrm{ml})$. The combined organic layers were washed with $\mathrm{HCl}(15 \mathrm{ml}, 1 \mathrm{M})$, brine $(15 \mathrm{ml})$ and dried $\left(\mathrm{MgSO}_{4}\right)$. After concentration the residue was purified by flash chromatography (Cy/EtOAc 5:1 to 1:1) to furnish the title compound $\mathbf{5}$ (74 $\mathrm{mg}, 0.21 \mathrm{mmol}, 72 \%)$ as a light yellow solid.

${ }^{1}$ H-NMR (300 MHz, CD $\left.{ }_{3} \mathrm{OD}\right): \delta 3.87(\mathrm{~s}, 6 \mathrm{H}), 4.65(\mathrm{~d}, J=3.1 \mathrm{~Hz}, 1 \mathrm{H}), 5.08(\mathrm{~d}, J=3.1 \mathrm{~Hz}$, 1H), $7.04\left(\mathrm{~m}_{\mathrm{c}}, 3 \mathrm{H}\right), 7.29\left(\mathrm{~m}_{\mathrm{c}}, 1 \mathrm{H}\right), 7.46(\mathrm{~d}, J=8.9 \mathrm{~Hz}, 1 \mathrm{H}) \mathrm{OH}$ not detected; ${ }^{13} \mathbf{C}-\mathbf{N M R}$ (75 MHz, $\left.\mathrm{CD}_{3} \mathrm{OD}\right): \delta 55.2,55.3,71.2,72.4,110.0,112.7,114.0,116.4,122.4,128.5,131.5$, 136.4, 137.8, 148.4, 157.6 (2C); HRMS: calcd. 350.0144 found 350.0154 ; mp: $185-188{ }^{\circ} \mathrm{C}$. 
rac-N,N'-(3-bromo-6,6'-dimethoxybiphenyl-2,2'-diyl)bis(methan-1-yl-1ylidene)dicyclohenanamine 12

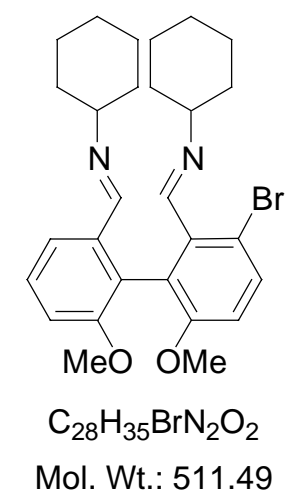

To a solution of rac-3-bromo-6,6'-dimethoxybiphenyl-2,2'-dicarbaldehyde 10 (825 mg, $2.36 \mathrm{mmol})$ in $\mathrm{CH}_{2} \mathrm{Cl}_{2}(10 \mathrm{ml})$ were added $\mathrm{MgSO}_{4}(600 \mathrm{mg})$ and cyclohexanamine $(672 \mu \mathrm{l}$, $585 \mathrm{mg}, 5.90 \mathrm{mmol}, 2.5 \mathrm{eq}$.). The resulting mixture was stirred at room temperature for $2.5 \mathrm{~h}$, the $\mathrm{MgSO}_{4}$ was filtered off and the solvent evaporated. Extensive drying at $60-70{ }^{\circ} \mathrm{C}(1 \mathrm{mbar})$ yielded the title compound $12(1.20 \mathrm{~g}, 2.35 \mathrm{mmol}, 99 \%)$ as a white foam.

${ }^{1}$ H-NMR (500 MHz, $\left.\mathrm{CDCl}_{3}\right): \delta 1.22\left(\mathrm{~m}_{\mathrm{c}}, 6 \mathrm{H}\right), 1.26\left(\mathrm{~m}_{\mathrm{c}}, 2 \mathrm{H}\right), 1.45\left(\mathrm{~m}_{\mathrm{c}}, 2 \mathrm{H}\right), 1.64\left(\mathrm{~m}_{\mathrm{c}}, 10 \mathrm{H}\right)$, $2.91\left(\mathrm{~m}_{\mathrm{c}}, 2 \mathrm{H}\right), 3.05(\mathrm{~s}, 3 \mathrm{H}), 3.20(\mathrm{~s}, 3 \mathrm{H}), 6.26(\mathrm{~d}, J=8.8 \mathrm{~Hz}, 1 \mathrm{H}), 6.54(\mathrm{~d}, J=8.2 \mathrm{~Hz}, 1 \mathrm{H})$, $7.17\left(\mathrm{~m}_{\mathrm{c}}, 1 \mathrm{H}\right), 7.41(\mathrm{~d}, J=8.8 \mathrm{~Hz}, 1 \mathrm{H}), 8.24(\mathrm{~d}, J=7.9 \mathrm{~Hz}, 1 \mathrm{H}), 8.31(\mathrm{~s}, 1 \mathrm{H}), 8.42(\mathrm{~s}, 1 \mathrm{H})$; ${ }^{13}$ C-NMR (125 MHz, $\left.\mathrm{CDCl}_{3}\right): \delta 24.4$ (2C), 24.7, 24.8, 26.0, 26.1, 34.0, 34.3, 35.0, 35.1, 55.3, 55.4, 69.7, 70.0, 111.7, 112.6, 114.1, 119.2, 126.8, 127.0, 128.4, 132.9, 137.6, 138.0, 156.3, 156.6, 157.3, 157.4; CHN: calcd. C: 62.75, H: 6.90, N: 5.48 found C: 62.80 H: 7.10 N: 5.49; mp: $50-51^{\circ} \mathrm{C}$. 


\section{rac-3-Chloro-6,6'-dimethoxybiphenyl-2,2'-dicarbaldehyde 13}

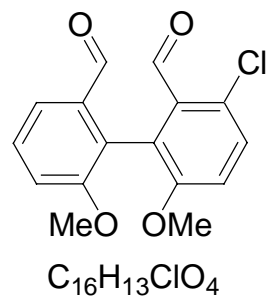

Mol. Wt.: 304.73

To a solution of rac- $N, N$ '-(3-bromo-6,6'-dimethoxybiphenyl-2,2'-diyl)bis(methan-1-yl-1ylidene)dicyclohexanamine $12(667 \mathrm{mg}, 1.30 \mathrm{mmol})$ in $\mathrm{THF}(3 \mathrm{ml})$ at $-78{ }^{\circ} \mathrm{C}$ was added $n$-BuLi (973 $\mu$ l, $1.43 \mathrm{mmol}, 1.1$ eq., $1.47 \mathrm{M}$ in hexane) dropwise and the mixture was stirred for $30 \mathrm{~min}$. Then solid perchloroethane $(1.85 \mathrm{~g}, 7.80 \mathrm{mmol}, 6.0 \mathrm{eq}$.) was added in one portion. The mixture was allowed to warm to room temperature and was heated to reflux for $2 \mathrm{~h}$. After cooling to room temperature $\mathrm{H}_{2} \mathrm{O}(5 \mathrm{ml})$ was added, the layers were separated and the aqueous phase extracted with MTBE $(2 \times 5 \mathrm{ml})$. The combined organic layers were dried $\left(\mathrm{MgSO}_{4}\right)$ and concentrated. The residue was dissolved in $\mathrm{CH}_{2} \mathrm{Cl}_{2}(10 \mathrm{ml}), \mathrm{HCl}(5 \mathrm{ml}, 2 \mathrm{M})$ was added and the mixture stirred for $6 \mathrm{~h}$ at room temperature. The layers were separated and the aqueous phase extracted with MTBE $(2 \times 5 \mathrm{ml})$. The combined organic layers were washed with $\mathrm{HCl}(2 \times 5 \mathrm{ml}, 2 \mathrm{M})$, dried $\left(\mathrm{MgSO}_{4}\right)$ and concentrated. The crude product was purified by flash chromatography $\left(\mathrm{CH}_{2} \mathrm{Cl}_{2}\right)$ to furnish the title compound 13 (265 mg, $0.87 \mathrm{mmol}, 67 \%$ ) as a white solid.

${ }^{1}$ H-NMR (500 MHz, $\mathrm{CDCl}_{3}$ ): $\delta 3.69$ (s, 3H), 3.72 (s, 3H), $7.10(\mathrm{~d}, J=8.8 \mathrm{~Hz}, 1 \mathrm{H}), 7.17$ (dd, $J=8.2,1.0 \mathrm{~Hz}, 1 \mathrm{H}), 7.49(\mathrm{~d}, J=8.8 \mathrm{~Hz}, 1 \mathrm{H}), 7.51\left(\mathrm{~m}_{\mathrm{c}}, 1 \mathrm{H}\right), 7.62(\mathrm{dd}, J=7.6,1.0 \mathrm{~Hz}, 1 \mathrm{H})$, $9.66(\mathrm{~s}, 1 \mathrm{H}), 10.16(\mathrm{~s}, 1 \mathrm{H}) ;{ }^{13} \mathrm{C}-\mathbf{N M R}\left(125 \mathrm{MHz}, \mathrm{CDCl}_{3}\right): \delta 56.1,56.3,115.9,116.1,120.4$, $125.5,126.5,127.8,129.5,131.5,133.1,135.4,156.2,156.5,190.4,191.6$; CH: calcd. C: 63.06, H: 4.30 found C: $62.94, \mathrm{H}: 4.28$; mp: $127-130{ }^{\circ} \mathrm{C}$. 


\section{rac-1-Chloro-4,5-dimethoxy-9,10-dihydrophenanthrene-9,10-diol 4}

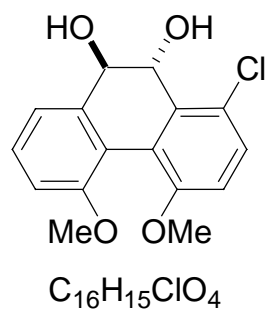

Mol. Wt.: 306.74

To a solution of $\mathrm{SmI}_{2}(6.00 \mathrm{ml}, 0.60 \mathrm{mmol}, 3.0$ eq., $0.1 \mathrm{M}$ in $\mathrm{THF})$ at $0{ }^{\circ} \mathrm{C}$ was added a solution of rac-3-Chloro-6,6'-dimethoxybiphenyl-2,2'-dicarbaldehyde $\mathbf{1 3}(61.0 \mathrm{mg}$, $0.20 \mathrm{mmol})$ in THF $(1.5 \mathrm{ml})$ over $15 \mathrm{~min}$. The mixture was stirred for $30 \mathrm{~min}$ at $0{ }^{\circ} \mathrm{C}$ and then allowed to warm to room temperature. After quenching the reaction mixture with $\mathrm{HCl}(30 \mathrm{ml}$, $1 \mathrm{M})$, the layers were separated and the aqueous layer was extracted with $\mathrm{CH}_{2} \mathrm{Cl}_{2}(3 \times 30 \mathrm{ml})$. The combined organic layers were washed with $\mathrm{HCl}(15 \mathrm{ml}, 1 \mathrm{M})$, brine $(15 \mathrm{ml})$ and dried $\left(\mathrm{Na}_{2} \mathrm{SO}_{4}\right)$. After concentration, the residue was purified by flash chromatography (Cy/EtOAc 1:1) to furnish the title compound 4 (34 mg, $0.11 \mathrm{mmol}, 55 \%)$ as a white solid.

${ }^{1}$ H-NMR (500 MHz, CD $\left.{ }_{3} \mathrm{OD}\right): \delta 3.86(\mathrm{~s}, 6 \mathrm{H}), 4.64(\mathrm{~d}, J=2.8 \mathrm{~Hz}, 1 \mathrm{H}), 5.11(\mathrm{~d}, J=2.8 \mathrm{~Hz}$, 1H), $7.04\left(\mathrm{~m}_{\mathrm{c}}, 3 \mathrm{H}\right), 7.29\left(\mathrm{~m}_{\mathrm{c}}, 2 \mathrm{H}\right) \mathrm{OH}$ not detected; ${ }^{13} \mathbf{C}-\mathbf{N M R}\left(125 \mathrm{MHz}, \mathrm{CD}_{3} \mathrm{OD}\right): \delta 56.3$, 56.5, 69.7, 73.4, 113.8, 114.7, 122.0, 123.6, 125.2, 127.9, 129.5, 129.7, 136.0, 138.9, 157.5, 158.8; HRMS: calcd. 306.0656 found 306.0659; mp: $218-221{ }^{\circ} \mathrm{C}$.

\section{rac-3-Hydroxy-6,6'-dimethoxybiphenyl-2,2'-dicarbaldehyde 14}

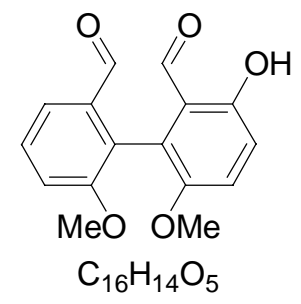

Mol. Wt.: 286.28

To a solution of $r a c-N, N$ '-(3-bromo-6,6'-dimethoxybiphenyl-2,2'-diyl)bis(methan-1-yl-1- 
ylidene)dicyclohexanamine 12 (900 $\mathrm{mg}, 1.76 \mathrm{mmol})$ in THF $(11 \mathrm{ml})$ at $-78{ }^{\circ} \mathrm{C}$ was added $n$-BuLi $(1.58 \mathrm{ml}, 1.93 \mathrm{mmol}, 1.1$ eq., $1.22 \mathrm{M})$ dropwise and the mixture was stirred for $45 \mathrm{~min}$. Then solid 3-phenyl-2-(phenylsulfonyl)-1,2-oxaziridine (686 mg, $2.63 \mathrm{mmol}, 1.5 \mathrm{eq}$.) was added in one portion and the resulting mixture stirred for $3 \mathrm{~h}$ at $-78{ }^{\circ} \mathrm{C}$. By the addition of $\mathrm{HCl}(3 \mathrm{ml}, 2 \mathrm{M})$ the reaction was quenched and allowed to warm to room temperature. The mixture was diluted with $\mathrm{H}_{2} \mathrm{O}(25 \mathrm{ml})$, the layers were separated and the aqueous phase was extracted with $\mathrm{CH}_{2} \mathrm{Cl}_{2}(3 \times 15 \mathrm{ml})$. The combined organic layers were extracted with $\mathrm{NaOH}$ $(3 \times 15 \mathrm{ml}, 6 \mathrm{M})$ and the resulting combined aqueous phases were washed with $\mathrm{CH}_{2} \mathrm{Cl}_{2}(15 \mathrm{ml})$. The aqueous phase was acidified with $\mathrm{HCl}(6 \mathrm{M})$, and then extracted with $\mathrm{CH}_{2} \mathrm{Cl}_{2}(3 \times 10 \mathrm{ml})$. The combined organic layers were washed with brine $(15 \mathrm{ml})$, dried $\left(\mathrm{MgSO}_{4}\right)$ and concentrated. The crude product was purified by flash chromatography (Cy/EtOAc 70:30) to yield the title compound $14(327 \mathrm{mg}, 1.14 \mathrm{mmol}, 65 \%)$ as a yellow solid.

${ }^{1}$ H-NMR (400 MHz, $\mathrm{CDCl}_{3}$ ): $\delta 3.64(\mathrm{~s}, 3 \mathrm{H}), 3.76(\mathrm{~s}, 3 \mathrm{H}), 7.05(\mathrm{dd}, J=9.1,0.6 \mathrm{~Hz}, 1 \mathrm{H}), 7.22$ $\left(\mathrm{m}_{\mathrm{c}}, 2 \mathrm{H}\right), 7.54\left(\mathrm{~m}_{\mathrm{c}}, 1 \mathrm{H}\right), 7.66(\mathrm{dd}, J=7.8,1.1 \mathrm{~Hz}, 1 \mathrm{H}), 9.48(\mathrm{~d}, J=0.6 \mathrm{~Hz}, 1 \mathrm{H}), 9.67(\mathrm{~d}, J=$ $0.9 \mathrm{~Hz}, 1 \mathrm{H}), 11.26(\mathrm{~s}, 1 \mathrm{H}) ;{ }^{13} \mathrm{C}-\mathrm{NMR}\left(100 \mathrm{MHz}, \mathrm{CDCl}_{3}\right): \delta 56.1,56.7,116.0,118.7,118.9$, 119.9, 121.4, 126.4, 129.1, 130.2, 136.1, 149.6, 156.6, 157.2, 191.6, 196.8; CH: calcd. C: 67.13, H: 4.93 found C: 66.92, H: 4.94; mp: $137-139{ }^{\circ} \mathrm{C}$.

\section{rac-3,6,6'-Trimethoxybiphenyl-2,2'-dicarbaldehyde 15}

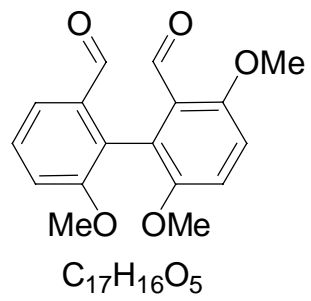

Mol. Wt.: 300.31

To a solution of rac-3-Hydroxy-6,6'-dimethoxybiphenyl-2,2'-dicarbaldehyde 14 (33 mg, 0.12 mmol) in DME ( $1 \mathrm{ml})$ was added aqueous $\mathrm{KOH}(68 \mu 1,1.2 \mathrm{mmol}, 10$ eq., $50 \%)$ and after 5 min dimethyl sulfate ( $55 \mu 1,73 \mathrm{mg}, 0.58 \mathrm{mmol}, 5$ eq.). The reaction mixture was stirred for 45 min at room temperature. After the addition of $\mathrm{H}_{2} \mathrm{O}(5 \mathrm{ml})$ and $\mathrm{CH}_{2} \mathrm{Cl}_{2}(5 \mathrm{ml})$ the layers were separated and the aqueous phase was extracted with $\mathrm{CH}_{2} \mathrm{Cl}_{2}(3 \times 5 \mathrm{ml})$. The combined organic layers were dried $\left(\mathrm{MgSO}_{4}\right)$ and concentrated. The residue was purified by flash chromatography (Cy/EtOAc 60:40) to yield the title compound 15 (27 mg, 0.09 mmol, $75 \%$ ) 
as a yellow solid.

${ }^{1} \mathbf{H}-\mathbf{N M R}\left(400 \mathrm{MHz}, \mathrm{CDCl}_{3}\right): \delta 3.64(\mathrm{~s}, 3 \mathrm{H}), 3.72(\mathrm{~s}, 3 \mathrm{H}), 3.93(\mathrm{~s}, 3 \mathrm{H}), 7.05(\mathrm{~d}, J=9.1 \mathrm{~Hz}$, 1H), $7.16\left(\mathrm{~m}_{\mathrm{c}}, 2 \mathrm{H}\right), 7.47\left(\mathrm{~m}_{\mathrm{c}}, 1 \mathrm{H}\right), 7.62(\mathrm{dd}, J=7.8,1.1 \mathrm{~Hz}, 1 \mathrm{H}), 9.43(\mathrm{~d}, J=0.9 \mathrm{~Hz}, 1 \mathrm{H})$, $10.21(\mathrm{~s}, 1 \mathrm{H}) ;{ }^{13} \mathrm{C}-\mathrm{NMR}\left(100 \mathrm{MHz}, \mathrm{CDCl}_{3}\right): \delta 56.1,56.3,56.5,112.6,116.0,117.2,119.7$, 124.7, 125.1, 128.3 129.1, 135.3, 151.3, 155.8, 156.8, 190.6, 192.0; CH: calcd. C: 67.99, H: 5.37 found $\mathrm{C}: 67.67, \mathrm{H}: 5.34$; mp: $124-126^{\circ} \mathrm{C}$.

\section{rac-1,4,5-Trimethoxy-9,10-dihydrophenanthrene-9,10-diol 6}

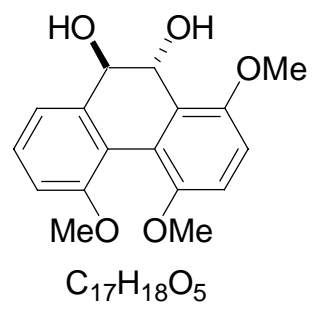

Mol. Wt.: 302.32

A mixture of Samarium (211 mg, $1.40 \mathrm{mmol}, 3.0$ eq.) and diiodoethane (381 mg, $1.35 \mathrm{mmol}$, 2.9 eq.) were suspended in THF (14 ml) and stirred at room temperature under exclusion of light for $2 \mathrm{~h}$. During this time the mixture was irradiated 4 times in an ultrasonic bath, each time for $5 \mathrm{~min}$. The resulting blue solution was then cooled to $0{ }^{\circ} \mathrm{C}$ and a solution of $\mathrm{rac}$ 3,6,6'-Trimethoxybiphenyl-2,2' -dicarbaldehyde 15 (140 mg, $0.47 \mathrm{mmol})$ in THF (3 ml) was added dropwise over $10 \mathrm{~min}$. The reaction mixture was stirred until complete consumption of the starting material and then allowed to warm to room temperature. After quenching with $\mathrm{HCl}(50 \mathrm{ml}, 1 \mathrm{M})$ the layers were separated and the aqueous layer was extracted with EtOAc $(5 \times 30 \mathrm{ml})$. The combined organic layers were washed with sat. aqueous $\mathrm{NaHCO}_{3}(15 \mathrm{ml})$, sat. aqueous $\mathrm{NaS}_{2} \mathrm{O}_{3}(15 \mathrm{ml})$, brine $(15 \mathrm{ml})$ and dried $\left(\mathrm{MgSO}_{4}\right)$. After concentration the residue was purified by flash chromatography (Cy/EtOAc 60:40) to furnish the title compound 6 (130 mg, $0.43 \mathrm{mmol}, 92 \%)$ as a white solid.

${ }^{1}$ H-NMR (500 MHz, CD 3 OD, T = $\left.257 \mathrm{~K}\right): \delta 3.83(\mathrm{~s}, 3 \mathrm{H}), 3.84(\mathrm{~s}, 3 \mathrm{H}), 3.86(\mathrm{~s}, 3 \mathrm{H}), 4.60(\mathrm{~d}, J$ $=3.2 \mathrm{~Hz}, 1 \mathrm{H}), 5.14(\mathrm{~d}, J=3.2 \mathrm{~Hz}, 1 \mathrm{H}), 6.95(\mathrm{~d}, J=9.1 \mathrm{~Hz}, 1 \mathrm{H}), 7.02(\mathrm{~d}, J=7.3 \mathrm{~Hz}, 1 \mathrm{H})$, $7.04(\mathrm{~d}, J=9.1 \mathrm{~Hz}, 1 \mathrm{H}), 7.06(\mathrm{~d}, J=8.5 \mathrm{~Hz}, 1 \mathrm{H}), 7.27(\mathrm{dd}, J=8.3,7.3 \mathrm{~Hz}, 1 \mathrm{H}) \mathrm{OH}$ not 
detected; ${ }^{13} \mathbf{C}-\mathbf{N M R}\left(125 \mathrm{MHz}, \mathrm{CD}_{3} \mathrm{OD}, \mathrm{T}=280 \mathrm{~K}\right): \delta 56.3,56.7,56.7,65.9,73.3,111.9$, 113.7, 114.3, 122.5, 123.7, 123.9, 126.5, 129.2, 138.9, 153.0, 154.0, 158.6; HRMS: calcd. 302.115904 found 302.115425 ; $\mathbf{m p}: 131-133{ }^{\circ} \mathrm{C}$.

Separation of enantiomers:

Preparative HPLC (AD-H, $n$-Heptane/iso-propanole 75:25, 16 ml/min, $230 \mathrm{~nm}$ ).

M- $(S, S)-6$ :

$\mathrm{t}_{\mathrm{R}}=27.61 \mathrm{~min}$ (analytical AD-H, $n$-heptane/iso-propanole 75:25, $0.8 \mathrm{ml} / \mathrm{min}, 230 \mathrm{~nm}$ ).

$[\alpha]_{\mathrm{D}}^{20}=+390.4^{\circ}(\mathrm{c}=1.09, \mathrm{MeOH})$.

ee $>99 \%$

$\mathrm{P}-(\mathrm{R}, \mathrm{R})-6$ :

$\mathrm{t}_{\mathrm{R}}: 30.60 \mathrm{~min}$ (analytical AD-H, $n$-heptane/iso-propanole 75:25, $0.8 \mathrm{ml} / \mathrm{min}, 230 \mathrm{~nm}$ ).

$[\alpha]_{\mathrm{D}}^{20}=-406.6^{\circ}(\mathrm{c}=1.01, \mathrm{MeOH})$.

ee $>99 \%$

rac-1-Fluoro-4,5-dimethoxy-9,10-dihydrophenanthrene-9,10-diol 3

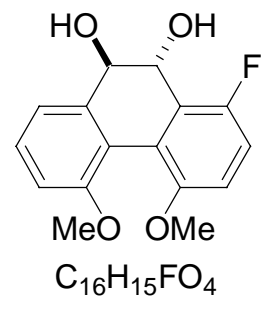

Mol. Wt.: 290.28

To a solution of rac- $N, N^{\prime}$-(3-bromo-6,6'-dimethoxybiphenyl-2,2'-diyl)bis(methan-1-yl-1ylidene)dicyclohexanamine $12(256 \mathrm{mg}, 0.50 \mathrm{mmol})$ in THF $(2 \mathrm{ml})$ at $-78{ }^{\circ} \mathrm{C}$ was added $n$-BuLi $(360 \mu 1,0.54 \mathrm{mmol}, 1.08$ eq., $1.51 \mathrm{M})$ dropwise and the mixture was stirred for $30 \mathrm{~min}$. Then solid $N$-fluoro- $N$-(phenylsulfonyl)benzenesulfonamide (310 mg, $0.98 \mathrm{mmol}, 1.96$ eq.) was added in one portion and the resulting mixture was allowed to warm to room temperature and stirred for $12 \mathrm{~h}$. After the addition of $\mathrm{HCl}(2 \mathrm{ml}, 2 \mathrm{M})$ and MTBE (5 ml) and stirring for $2 \mathrm{~h}$ the layers were separated and the aqueous layer was extracted with MTBE $(3 \times 5 \mathrm{ml})$. The combined organic layers were washed with $\mathrm{HCl}(2 \times 10 \mathrm{ml}, 2 \mathrm{M})$, brine $(10 \mathrm{ml})$, dried $\left(\mathrm{MgSO}_{4}\right)$ and concentrated. The residue was submitted to flash chromatography $\left(\mathrm{CH}_{2} \mathrm{Cl}_{2}\right)$ which 
furnished an inseparable mixture of the monofluorinated bisaldehyde and 9 (117 $\mathrm{mg})$ which was directly used in the next step. A mixture of Samarium (149 mg, $0.99 \mathrm{mmol}, 2.6$ eq.) and diiodoethane (268 mg, $0.95 \mathrm{mmol}, 2.5$ eq.) were suspended in THF $(10 \mathrm{ml})$ and stirred at room temperature under exclusion of light for $2 \mathrm{~h}$. During this time the mixture was irradiated 4 times in an ultrasonic bath, each time for $5 \mathrm{~min}$. The resulting blue solution was then cooled to $0^{\circ} \mathrm{C}$ and a solution of the mixture in THF $(2 \mathrm{ml})$ was added dropwise over $10 \mathrm{~min}$. The reaction mixture was stirred $30 \mathrm{~min}$ at $0{ }^{\circ} \mathrm{C}$ and allowed to warm to room temperature. After quenching with $\mathrm{HCl}(50 \mathrm{ml}, 1 \mathrm{M})$ the layers were separated and the aqueous layer was extracted with EtOAc $(5 \times 30 \mathrm{ml})$. The combined organic layers were washed with sat. aqueous $\mathrm{NaHCO}_{3}(15 \mathrm{ml})$, sat. aqueous $\mathrm{NaS}_{2} \mathrm{O}_{3}(15 \mathrm{ml})$, brine $(15 \mathrm{ml})$ and dried $\left(\mathrm{MgSO}_{4}\right)$. After concentration the residue was purified by preparative HPLC (Si60, MTBE/EtOAc 75:25, $16 \mathrm{ml} / \mathrm{min}, 269 \mathrm{~nm})$ which furnished the title compound $3(27 \mathrm{mg}, 0.09 \mathrm{mmol}, 19 \%$ over 3 steps) as a white solid.

${ }^{1}$ H-NMR $\left(500 \mathrm{MHz}, \mathrm{CD}_{3} \mathrm{OD}, \mathrm{T}=260 \mathrm{~K}\right): \delta 3.86(\mathrm{~s}, 3 \mathrm{H}), 3.88(\mathrm{~s}, 3 \mathrm{H}), 4.63(\mathrm{~d}, J=2.9 \mathrm{~Hz}$, $1 \mathrm{H}), 5.01(\mathrm{~d}, J=2.8 \mathrm{~Hz}, 1 \mathrm{H}), 7.01-7.11(\mathrm{~m}, 4 \mathrm{H}), 7.30(\mathrm{dd}, J=8.5,7.3 \mathrm{~Hz}, 1 \mathrm{H}) \mathrm{OH}$ not detected; ${ }^{13} \mathbf{C}$-NMR $\left(125 \mathrm{MHz}, \mathrm{CD}_{3} \mathrm{OD}, \mathrm{T}=260 \mathrm{~K}\right): \delta 56.2,56.7,65.3,72.9,113.7,114.5(\mathrm{~d}$, $J=9.3 \mathrm{~Hz}), 115.2(\mathrm{~d}, J=24.4 \mathrm{~Hz}), 121.7,123.7,124.0,125.0,129.6,138.7,154.8,156.6(\mathrm{~d}$, $J=236.4 \mathrm{~Hz}$ ), 158.6; ${ }^{19}$ F-NMR (235 MHz): $\delta$-131.1 (br s); CH: calcd. C: $66.20 \mathrm{H}: 5.21$ found C: $66.11 \mathrm{H}: 5.20$; mp: $178-181{ }^{\circ} \mathrm{C}$; HPLC: $\mathrm{t}_{\mathrm{R}}$ : $3.50 \mathrm{~min}$ (analytical Si60, MTBE /EtOAc 75:25, $1 \mathrm{ml} / \mathrm{min}, 269 \mathrm{~nm})$. 


\section{Density Functional Calculations}

All density functional calculations were performed with Gaussian03. ${ }^{[1]}$ For the Diols 2-6 the biseq. conformer and the bisax. conformer were optimized at the B3LYP/6-31G* level and each optimized structure was submitted to a single point calculation at B3LYP/6$311+\mathrm{G}(3 \mathrm{df}, 2 \mathrm{p})$ level (Table 1).

Table 1. Density functional calculations of molecules 2-6 with B3LYP/6-311+G(3df,2p)//B3LYP/6-31G* using Gaussian03. ${ }^{[1]} \mathrm{E}_{\text {rel. }}$ : relative energy; $\mathrm{E}_{\text {rel.(zpe): }}$ : zeropoint corrected relative energy; $\mathrm{n}_{\text {imag.: }}$ number of imaginary frequencies.

\begin{tabular}{cccccc}
\hline entry & molecule & conformation & $\mathrm{E}_{\text {rel. }} / \mathrm{kcal} / \mathrm{mol}$ & $\mathrm{E}_{\text {rel.(zpe) }} / \mathrm{kcal} / \mathrm{mol}$ & $\mathrm{n}_{\text {imag. }}$ \\
\hline 1 & \multirow{2}{*}{$\mathbf{2}$} & biseq. & 0 & 0 & 0 \\
2 & & bisax. & 1.50 & 1.45 & 0 \\
\hline 3 & $\mathbf{3}$ & biseq. & 0 & 0 & 0 \\
4 & & bisax. & 1.51 & 1.36 & 0 \\
\hline 5 & \multirow{4}{*}{$\mathbf{4}$} & biseq. & 2.08 & 2.15 & 0 \\
6 & & bisax. & 0 & 0 & 0 \\
\hline 7 & $\mathbf{5}$ & biseq. & 2.30 & 2.40 & 0 \\
8 & & bisax. & 0 & 0 & 0 \\
\hline 9 & \multirow{2}{*}{$\mathbf{6}$} & biseq. & 0 & 0 & 0 \\
\hline 10 & & bisax. & 2.11 & 1.77 & 0 \\
\hline
\end{tabular}

For the simulated CD spectra the structures were optimized (B3LYP/6-31G*) and submitted to a TDDFT calculation (TDB3LYP/TZVP), covering 25 singlet excitations. The obtained rotatory strengths were multiplied with Gaussian functions using a linewidth of $9 \mathrm{~nm}$ to give the total CD spectrum. ${ }^{[11,16]}$ 
IV NMR Spectra
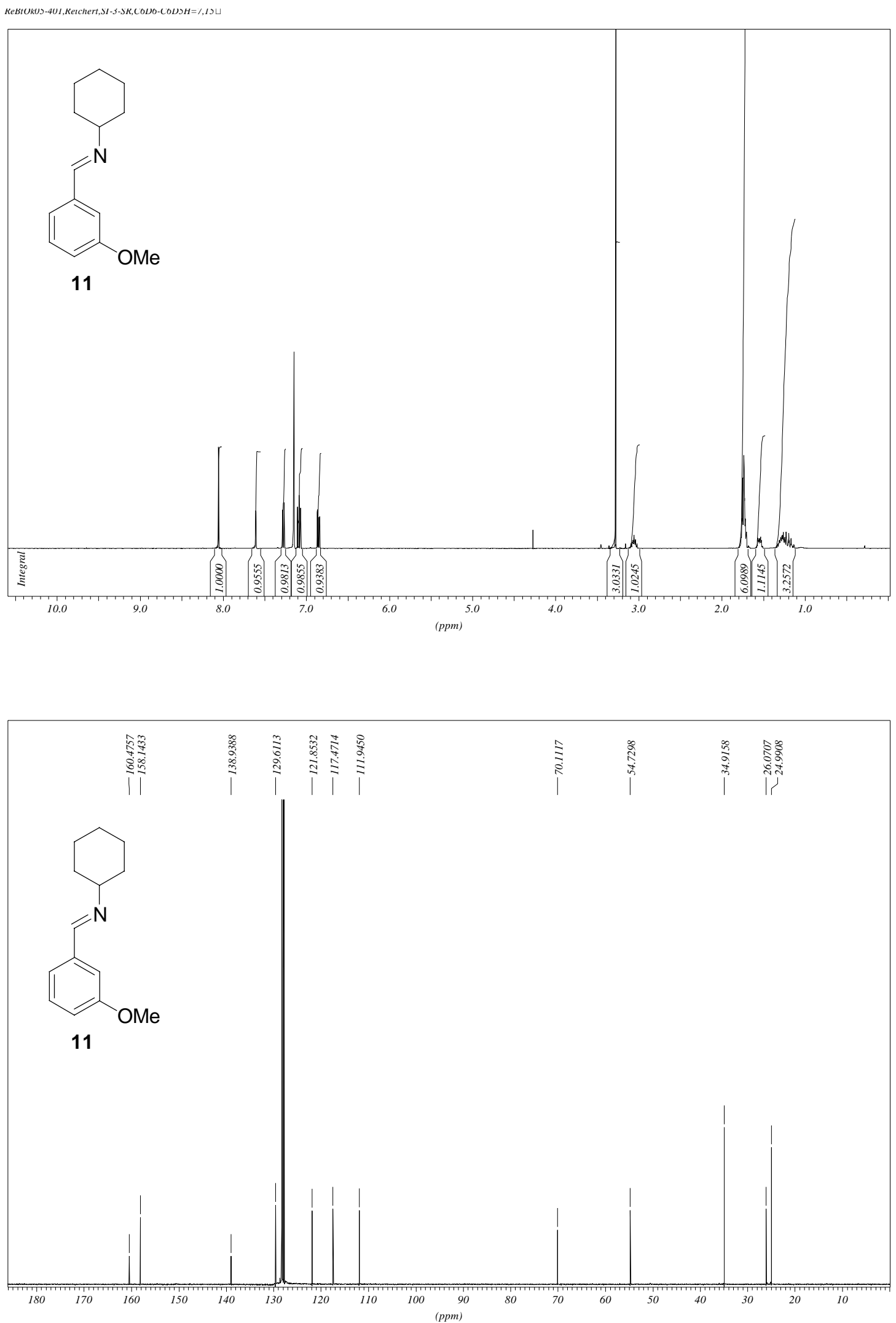

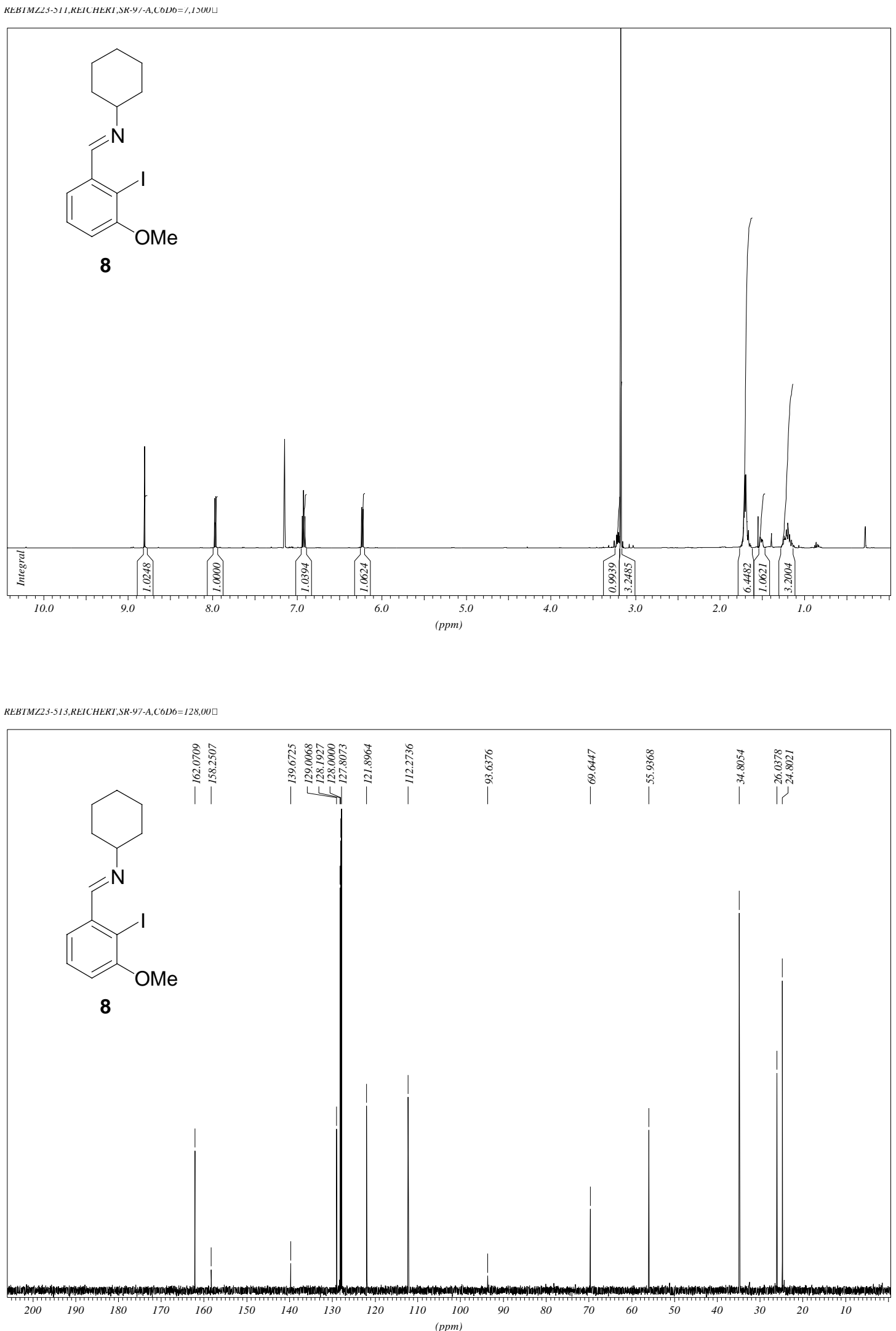


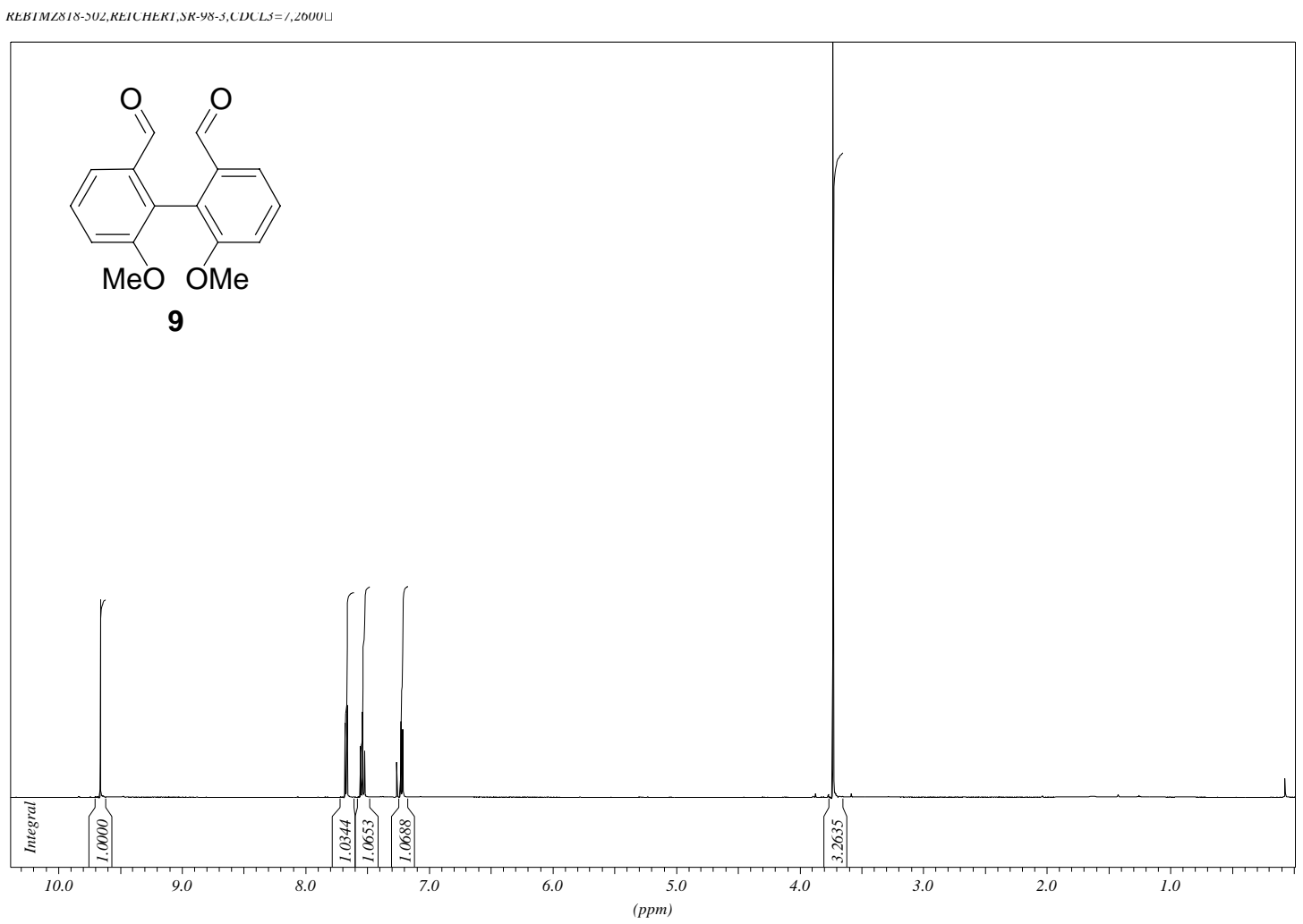

REBIMLXIX-SU4,REICHERI,SK-YX-S, CDCLS $=/ /, I \sqcup$

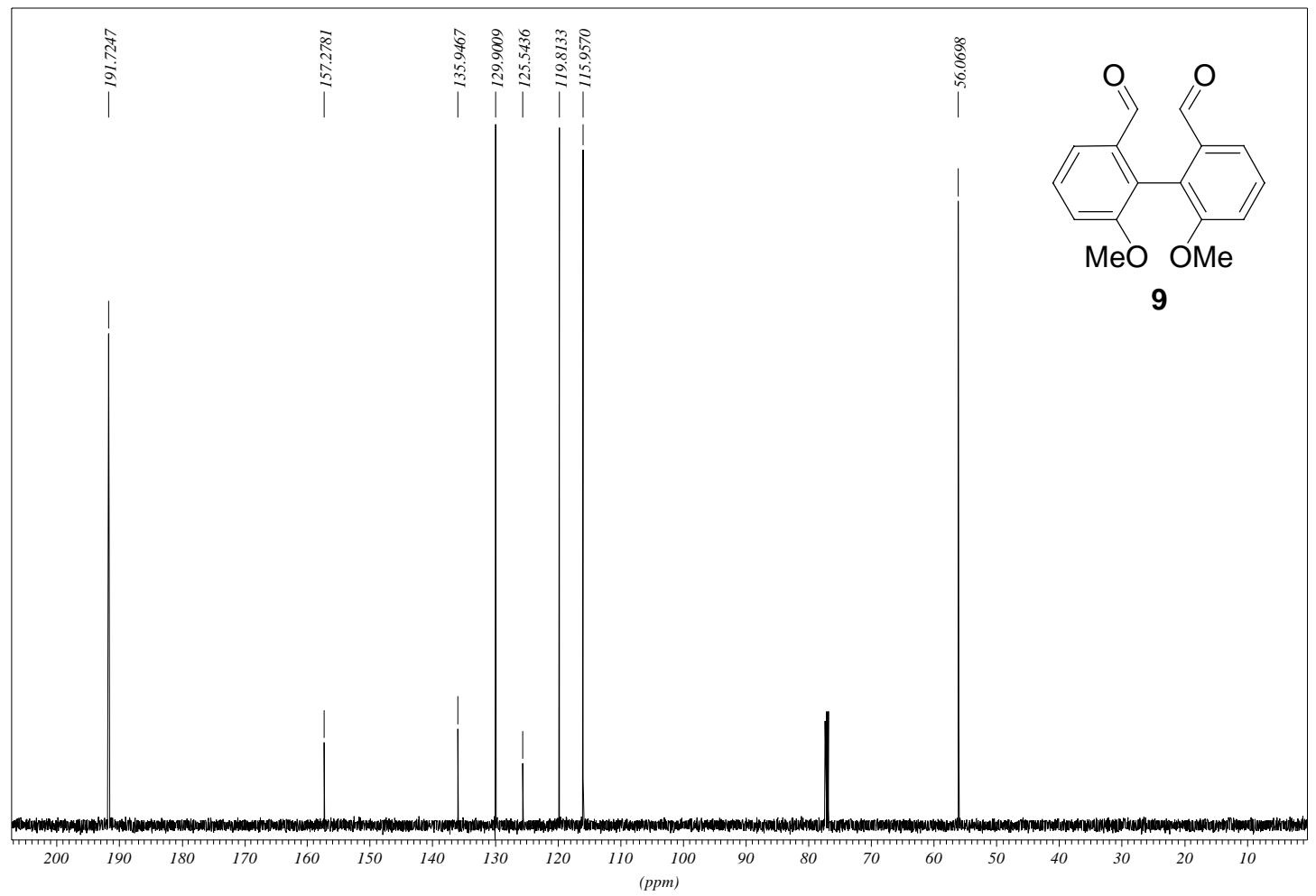



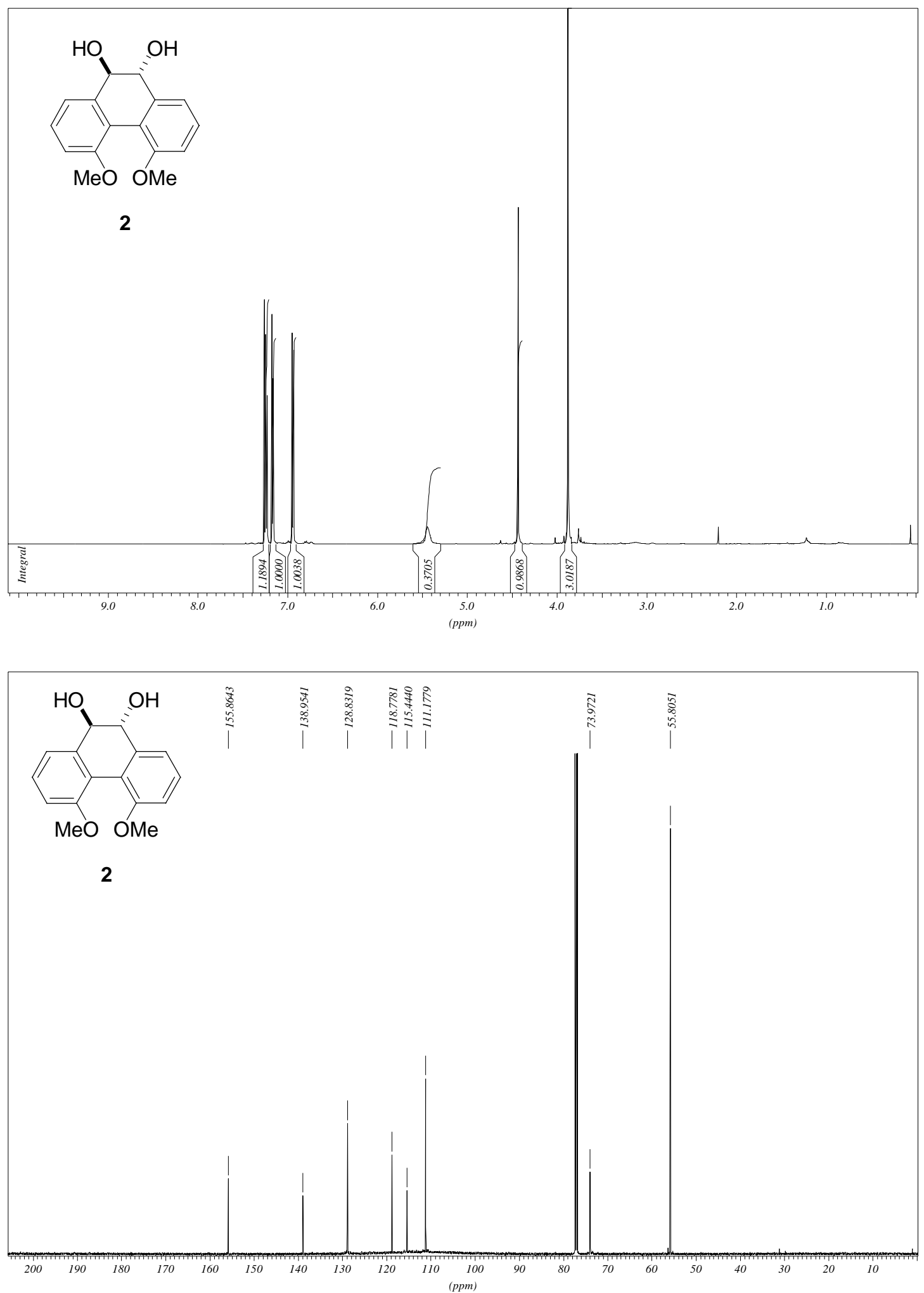

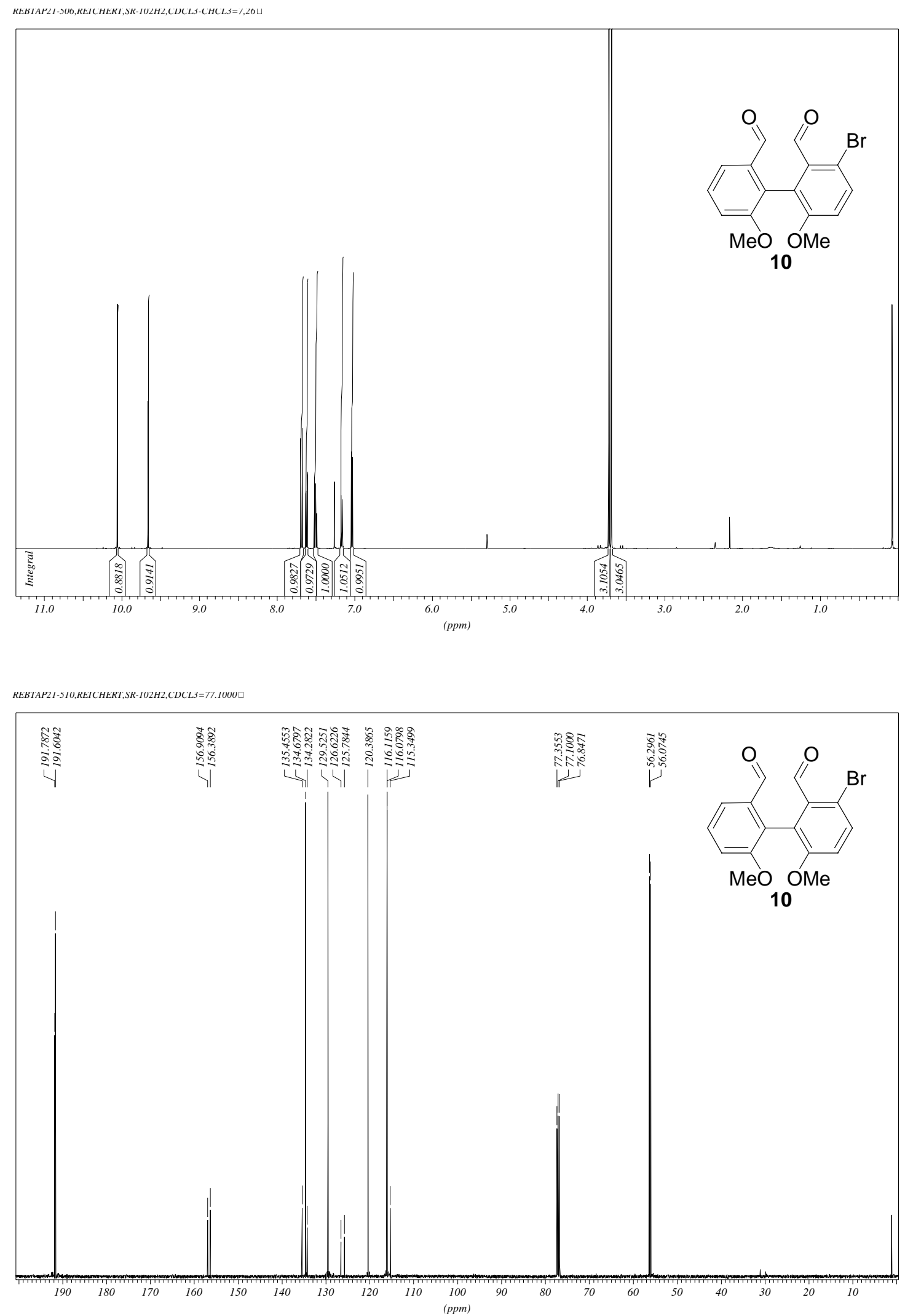

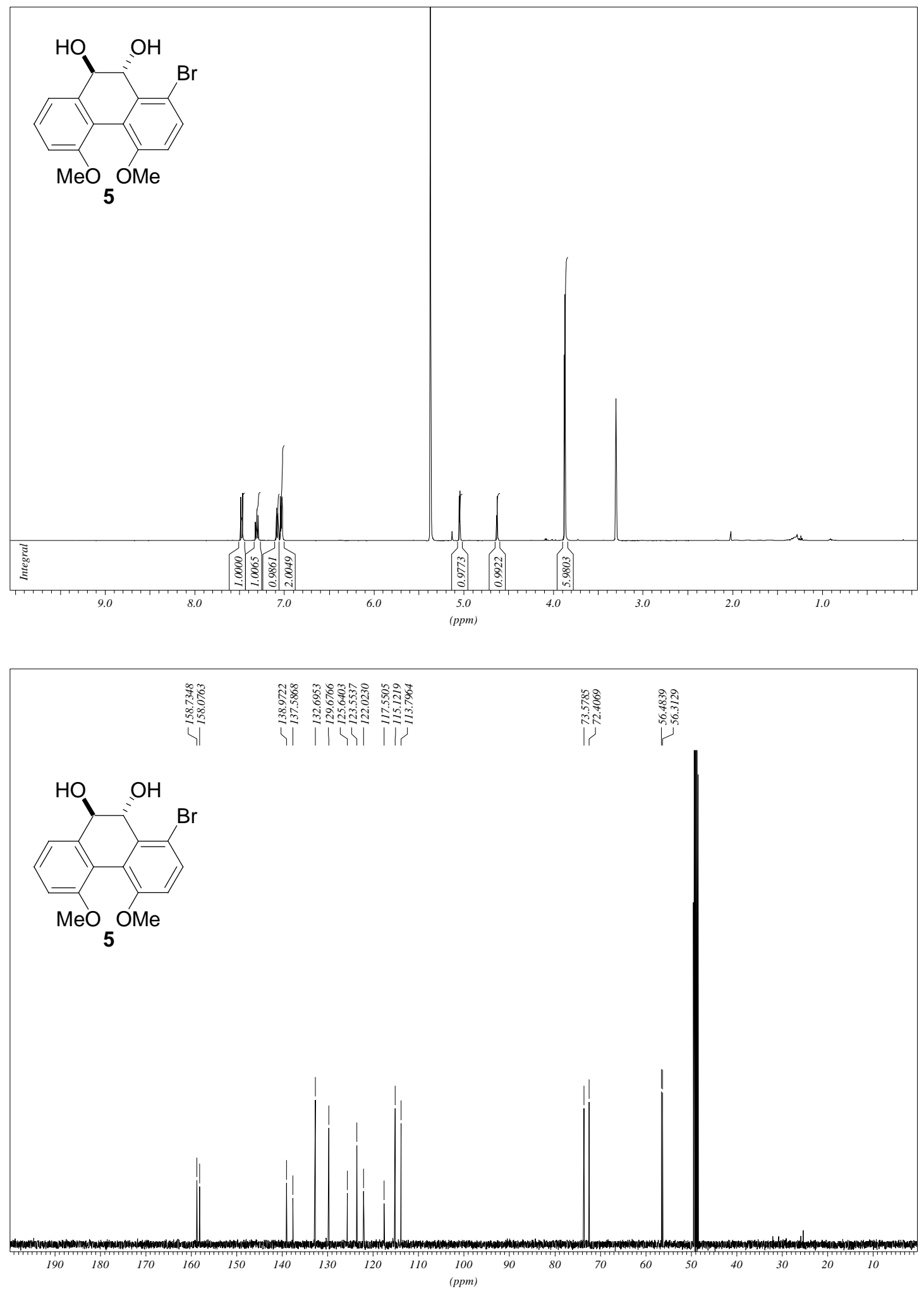

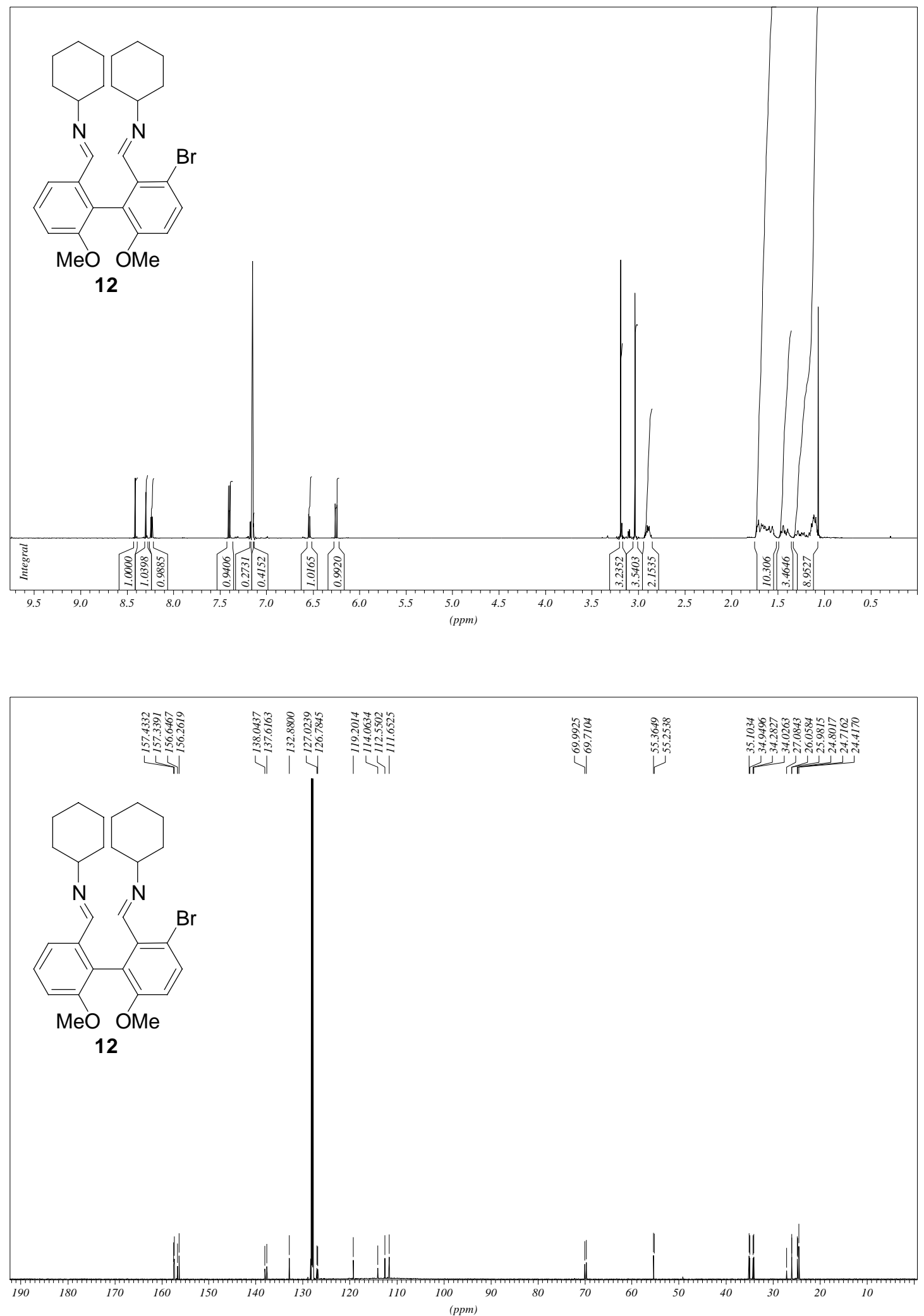

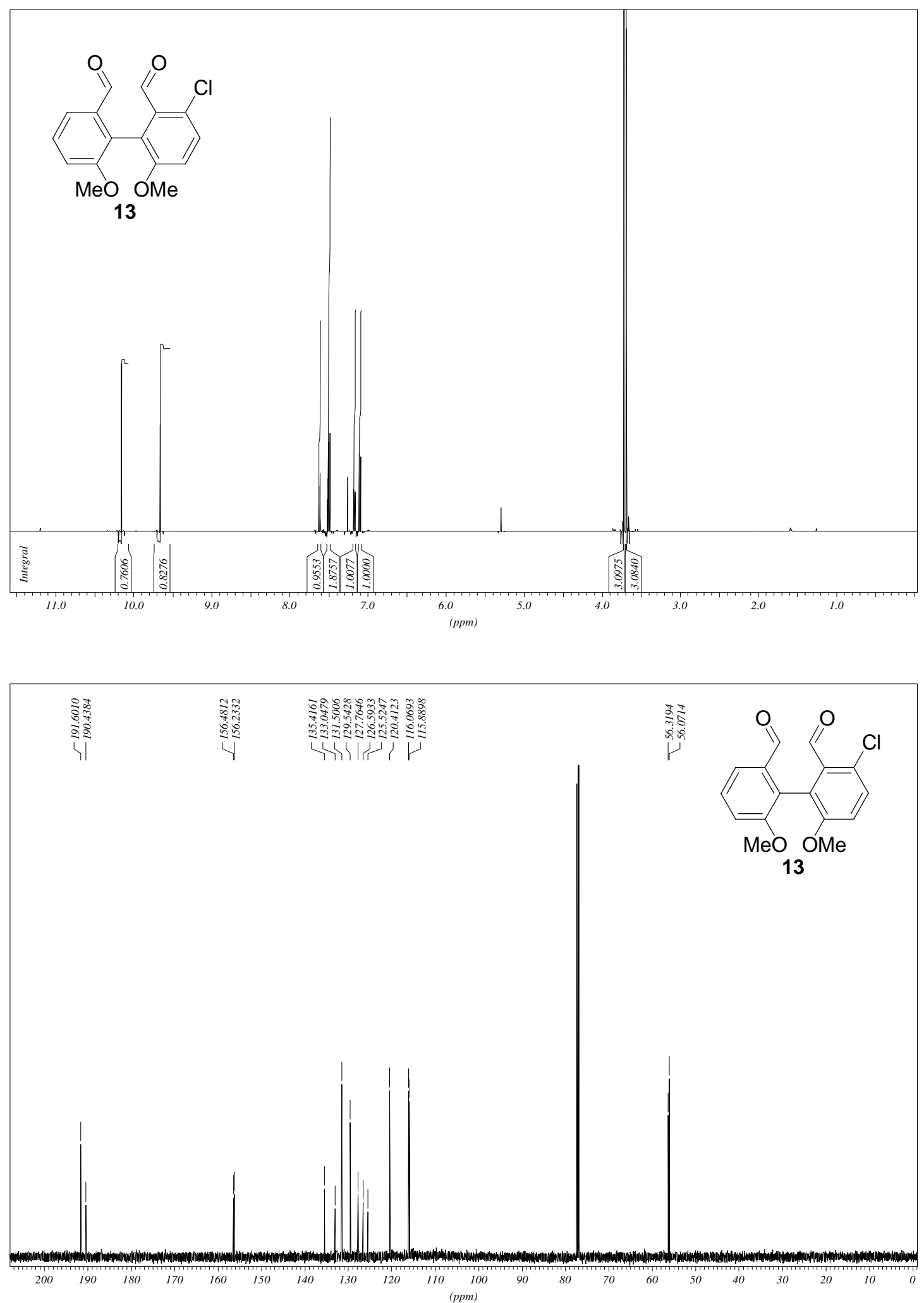


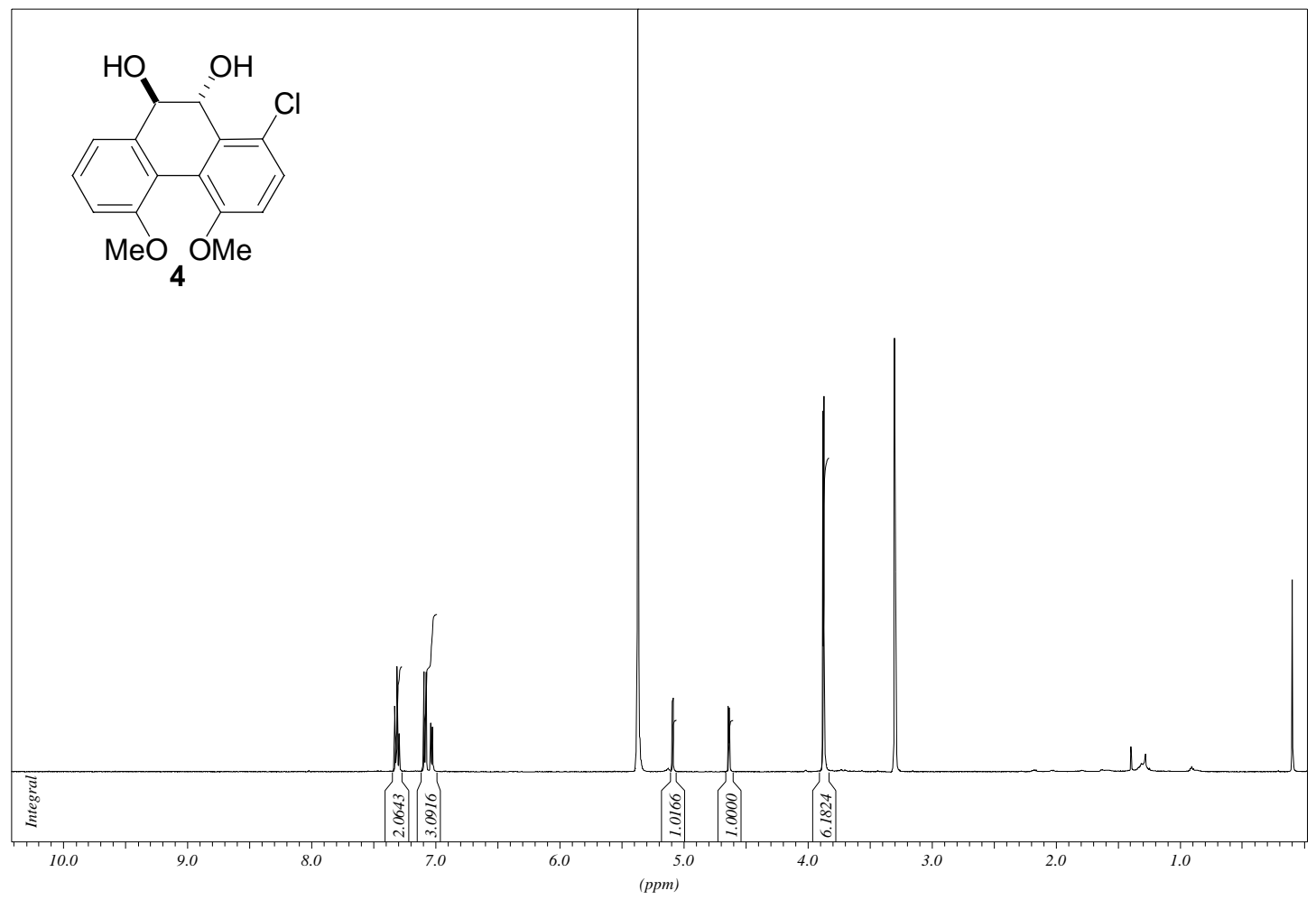

KIBIUKIS-4UZ4,KEICHERI,SK-I48-FIM,CDSUD=44,UL

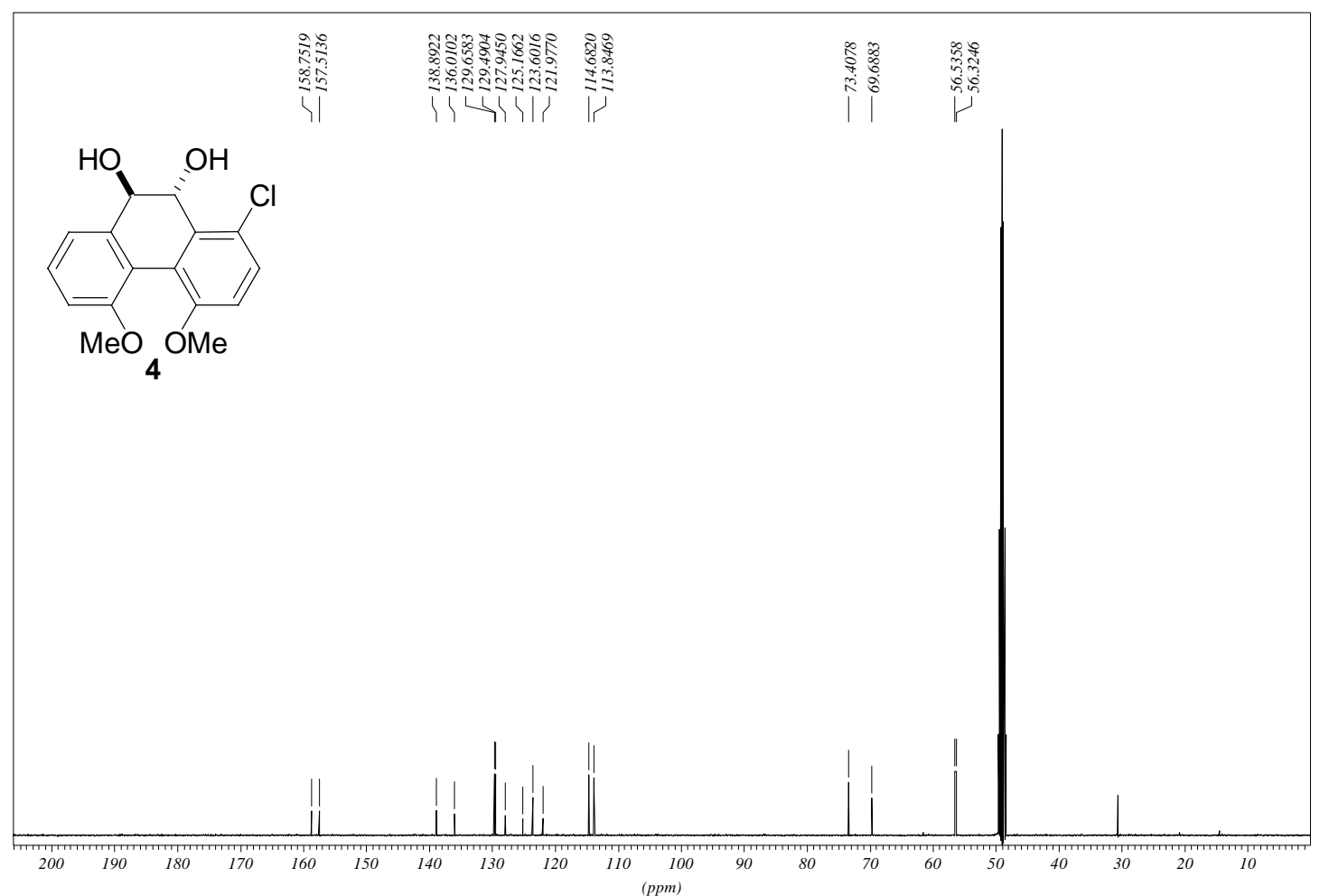



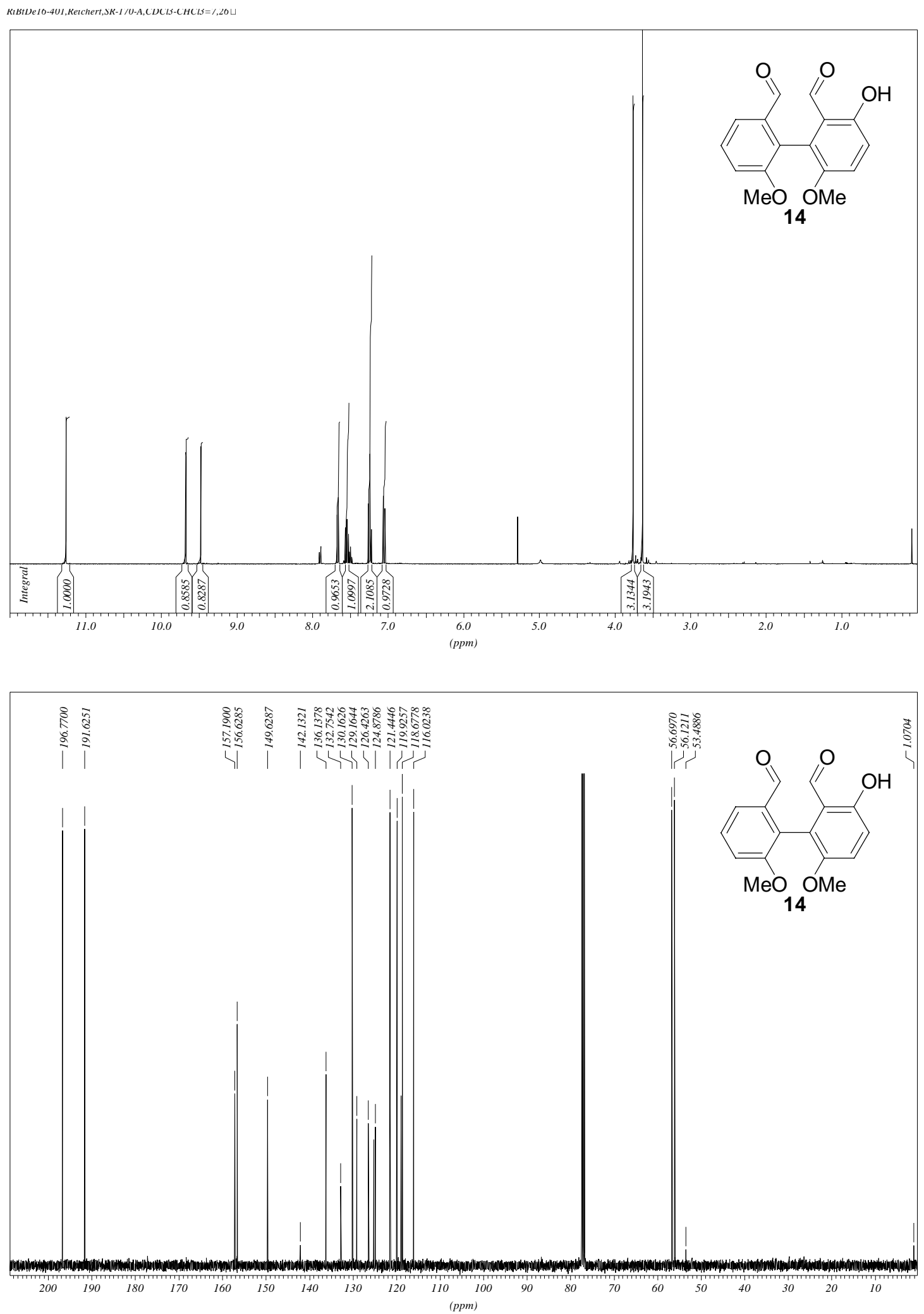

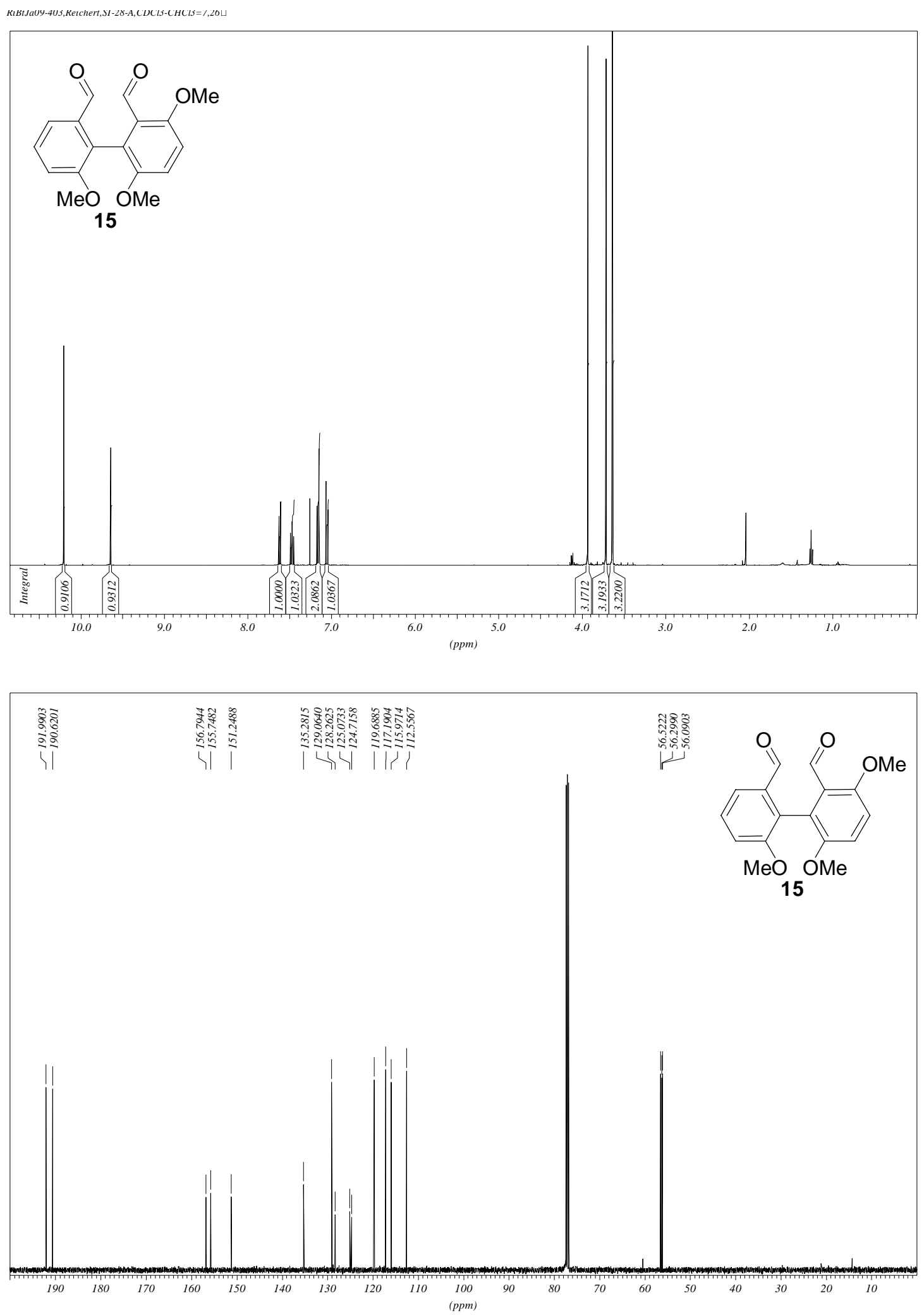

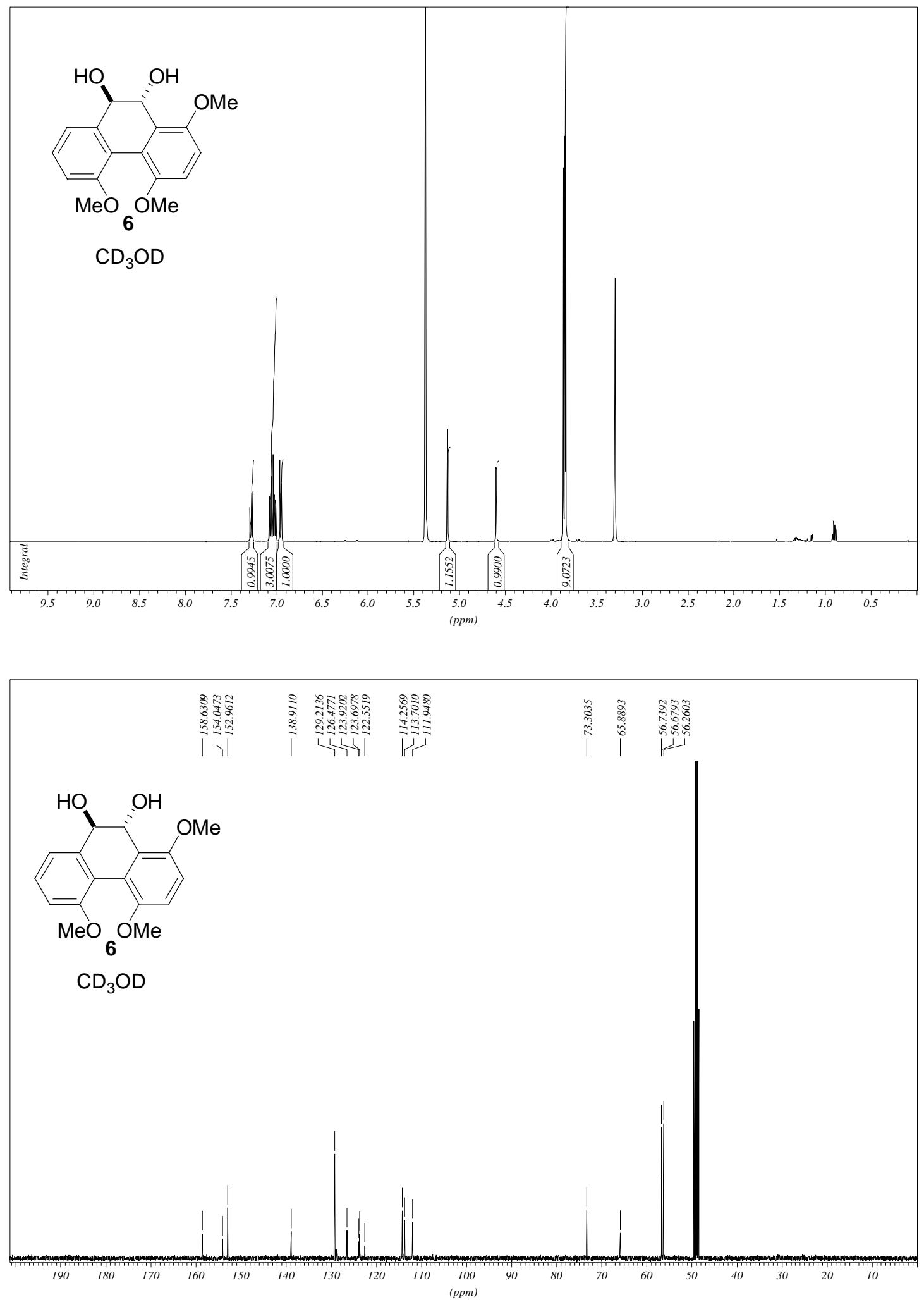


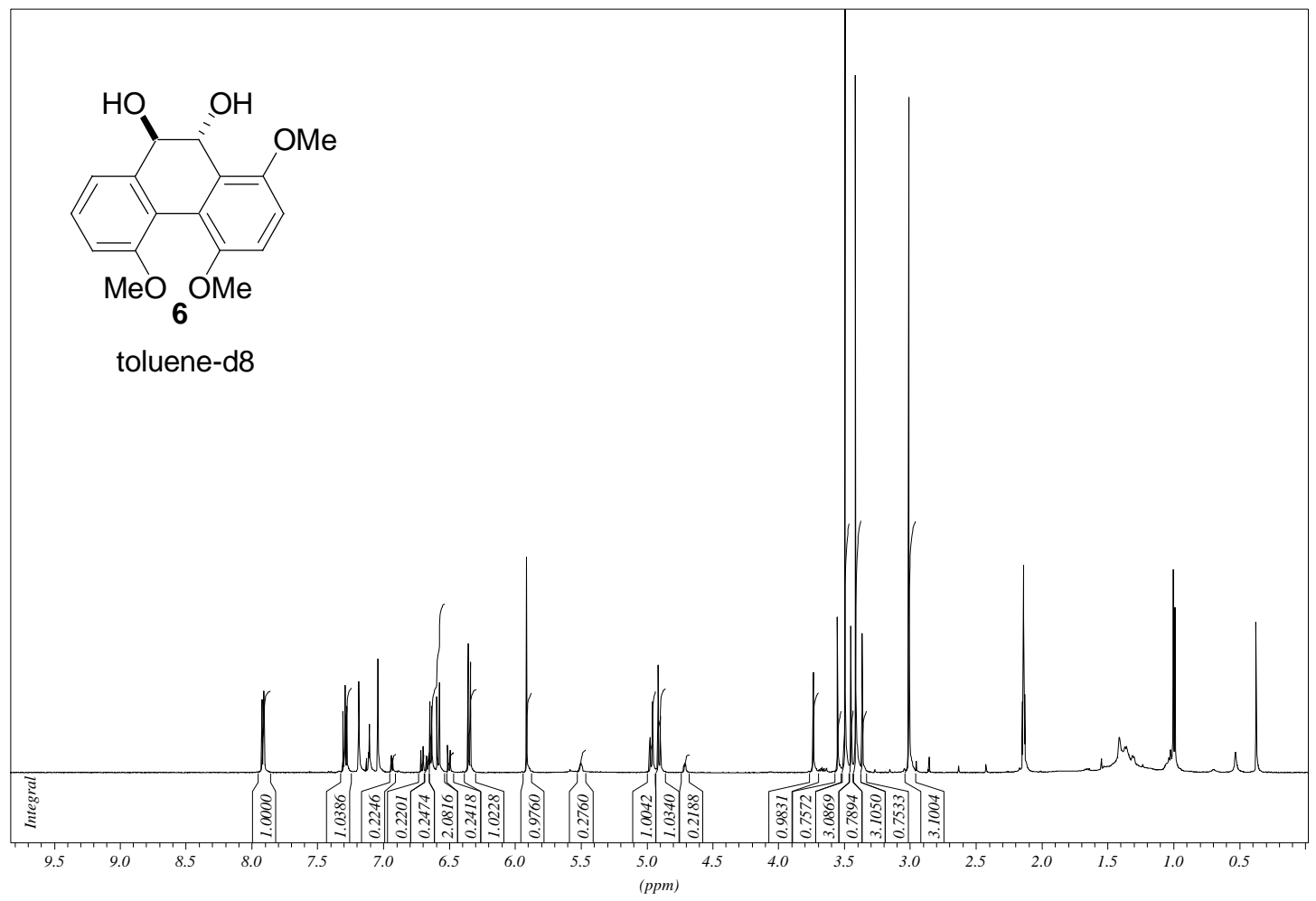

Temperature dependent NMR experiments of $\mathbf{6}$

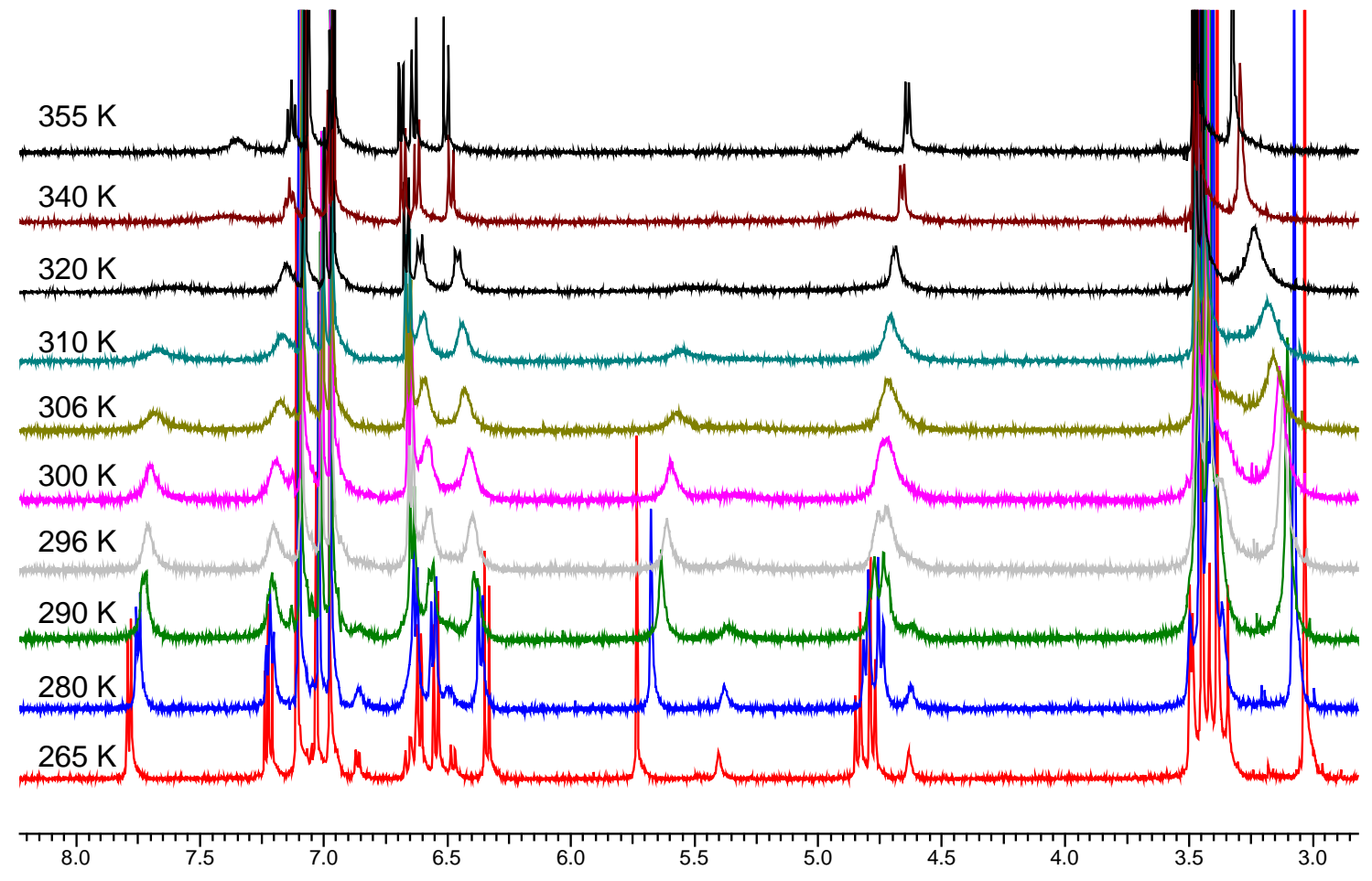



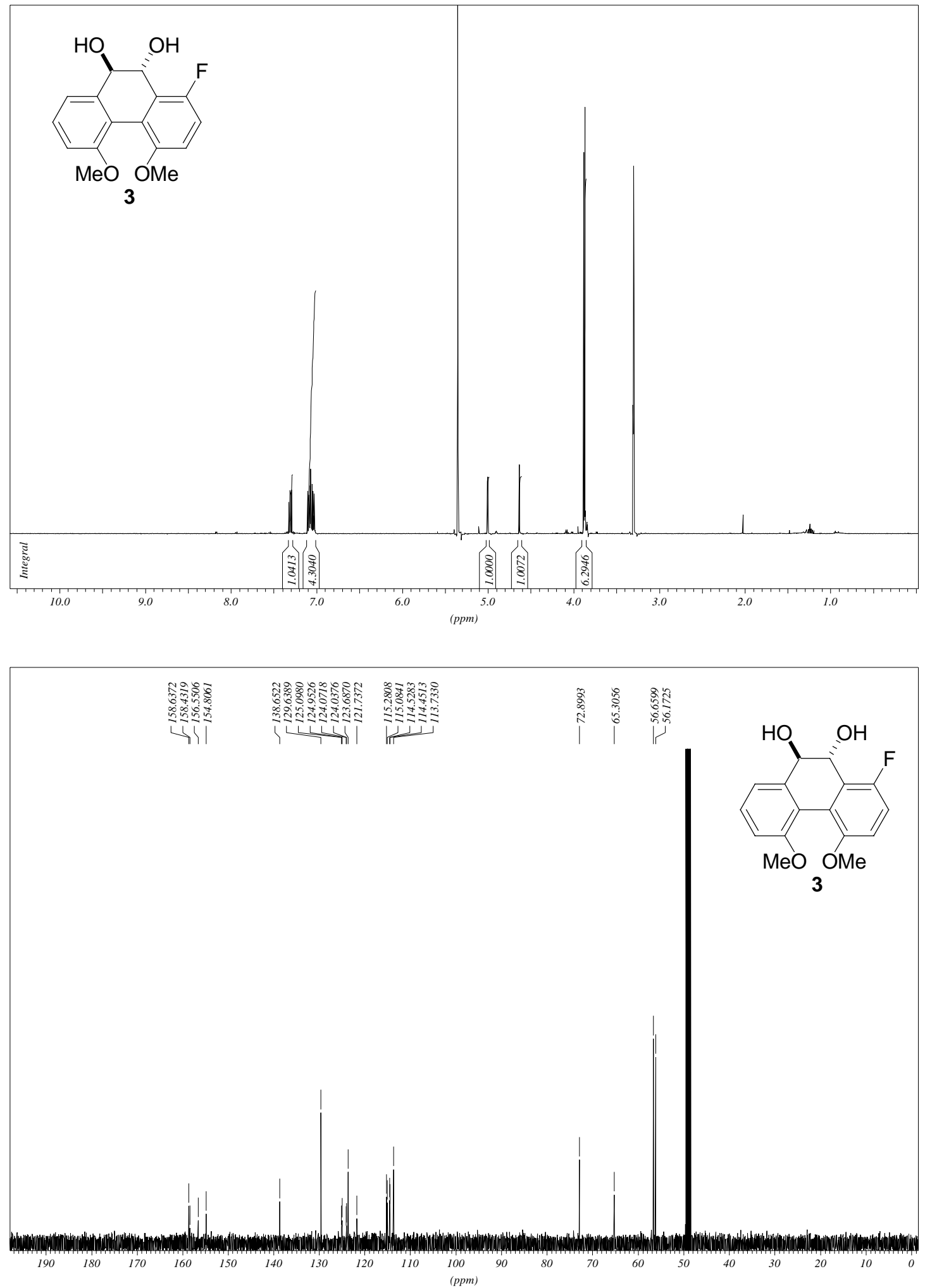
(a) Eelkema, R.; Pollard, M. M.; Vicario, J.; Katsonis, N.; Ramon, B. S.; Bastiaansen, C. W. M.; Broer, D. J.; Feringa, B. L. Nature 2006, 440, 163. (b) Kinbara, K.; Aida, T. Chem. Rev. 2005, 105, 13771400. (c) Feringa, B. L.; van Delden, R. A.; ter Wiel, M. K. J. Pure Appl. Chem. 2003, 75, 563-575. (d) Balzani, V.; Credi, A.; Raymo, F. M.; Stoddart, J. F. Angew. Chem. Int. Ed. 2000, 39, 3348-3391. (e) Kelly, T. R.; de Silva, H.; Silva, R. A. Nature 1999, 401, 150-152. (f) Koumura, N.; Zijlstra, R. W. J.; van Delden, R. A.; Harada, N.; Feringa, B. L. Nature 1999, 401, 152-154.

(2) (a) Balzani, V.; Credi, A.; Silvi, S.; Venturi, M. Chem. Soc. Rev. 2006, 35, 1135-1149. (b) Qu, D.-H.; Wang, Q.-C.; Ren, J.; Tian, H. Org. Lett. 2004, 6, 2085-2088. (c) Brouwer, A. M.; Frochot, C.; Gatti, F. G.; Leigh, D. A.; Mottier, L.; Paolucci, F.; Roffia, S.; Wurpel, G. W. H. Science 2001, 291, 2124-2128.

(a) Karle, M.; Bockelmann, D.; Schumann, D.; Griesinger, C.; Koert, U. Angew. Chem. Int. Ed. 2003, 42, 4546-4594. (b) Yuasa, H.; Hashimoto, H. J. Am. Chem. Soc. 1999, 121, 5089-5090.

(a) Brayshaw, S. K.; Green, J. C.; Hazari, N.; McIndoe, J. S.; Marken, F.; Raihby, P. R.; Weller, A. S. Angew. Chem. Int. Ed. 2003, 45, 6005-6008. (b) Rathore, R.; Le Magueres, P.; Lindeman, S. V.; Kochi, J. K. Angew. Chem. Int. Ed. 2000, 39, 809-812.

(a) Feringa, B. L.; van Delden, R. A.; Koumura, N.; Geertsma, E. M. Chem. Rev. 2000, 100, 1789-1816.

(b) Shinkai, S.; Minami, T.; Kusano, Y.; Manabe, O. J. Am. Chem. Soc. 1983, 105, 1851-1856.

(a) Eguchi, T.; Kondo, K.; Kakinuma, K.; Uekusa, H.; Ohashi, Y.; Mizoue, K.; Qiao, Y.-F. J. Org. Chem. 1999, 64, 5371-5376. (b) Qiao, Y.; Okazaki, T.; Ando, T.; Mizoue, K.; Kondo, K.; Eguchi, T.; Kakinuma, K. J. Antibiot. 1998, 51, 288-295.

(7) $\mu$ : dipole moment in Debye, $\varepsilon_{\mathrm{r}}$ : dielectricity constant, $\mathrm{E}_{\mathrm{T}}^{\mathrm{N}}$ : normalized polarity parameter from: Reichardt, C. Solvents and Solvent Effects in Organic Chemistry, Wiley-VCH, Weinheim, 2003.

(9) For conformational investigations on 9,10-dihydrophenanthrene derivatives see: (a) Cobb, D. I.; Lewis, A.; Armstrong, R. N. J. Org. Chem. 1983, 48, 4139-4141. (b) Armstrong, R. N.; Lewis, D. A.; Ammon, H. L.; Prasad, S. M. J. Am. Chem. Soc. 1985, 107, 1057-1058. (c) Darnow, J. N.; Armstrong, R. N. J. Am. Chem. Soc. 1990, 112, 6725-6726.

(10) Hoffmann, R. W. Chem. Rev. 1989, 89, 1841-1860.

(11) (a) Kyba, E. B.; Koga, K.; Sousa, L. R.; Siegel, M. G.; Cram, D. J. J. Am. Chem. Soc. 1973, 95, 26922693. (b) Noyori, R.; Tomino, I.; Tanimoto, Y.; Nishizawa, M.; J. Am. Chem. Soc. 1984, 106, 67096716. (c) For a review see: Brunel, J. M. Chem. Rev. 2005, 105, 857-897.

(12) Gaussian 03 (Revision B.04), Frisch, M. J.; Trucks, G. W; Schlegel, H. B; Scuseria, G. E.; Robb, M. A.; Cheeseman, J. R.; Montgomery, Jr., J. A.; Vreven, T.; Kudin, K. N.; Burant, J. C.; Millam, J. M.; Iyengar, S. S.; Tomasi, J.; Barone, V.; Mennucci, B.; Cossi, M.; Scalmani, G.; Rega, N.; Petersson, G. A.; Nakatsuji, H.; Hada, M.; Ehara, M.; Toyota, K.; Fukuda, R.; Hasegawa, J.; Ishida, M.; Nakajima, T.; Honda, Y.; Kitao, O.; Nakai, H.; Klene, M.; Li, X.; Knox, J. E.; Hratchian, H. P.; Cross, J. B.; Adamo, C.; Jaramillo, J.; Gomperts, R.; Stratmann, R. E.; Yazyev, O.; Austin, A. J.; Cammi, R.; Pomelli, C.; Ochterski, J. W.; Ayala, P. Y.; Morokuma, K.; Voth, G. A.; Salvador, P.; Dannenberg, J. J.; Zakrzewski, V. G.; Dapprich, S.; Daniels, A. D.; Strain, M. C.; Farkas, O.; Malick, D. K.; Rabuck, A. D.; Raghavachari, K.; Foresman, J. B.; Ortiz, J. V.; Cui, Q.; Baboul, A. G.; Clifford, S.; Cioslowski, J.; 
Stefanov, B. B.; Liu, G.; Liashenko, A.; Piskorz, P.; Komaromi, I.; Martin, R. L.; Fox, D. J.; Keith, T.; Al-Laham, M. A.; Peng, C. Y.; Nanayakkara, A.; Challacombe, M.; Gill, P. M. W.; Johnson, B.; Chen, W.; Wong, M. W.; Gonzalez, C.; and Pople, J. A. Gaussian, Inc., Pittsburgh PA, 2003.

(13) Flippin, L. A.; Muchowski, J. M.; Carter, D. S. J. Org. Chem. 1993, 58, 2463-2467.

(14) Liebeskind, L. S.; Zhang, S.; Zhang, D. J. Org. Chem. 1997, 62, 2312-2313.

(15) Ohmori, K.; Kitamura, M.; Suzuki, K. Angew. Chem. Int. Ed. 1999, 38, 1226-1229.

(16) Bringmann, G; Mortimer, A. J.; Keller, P. A.; Gresser, M. J.; Garner, J.; Breuning, M. Angew. Chem. Int. Ed. 2005, 44, 5384-5427.

(17) Footnote

(18) (a) Lakshman, M. K.; Xiao, W.; Sayer, J. M.; Cheh, A. M.; Jerina, D. M. J. Org. Chem. 1994, 59, 17551760. (b) Gawroński, J.; Grycz, P.; Kwit, M.; Rychlewska, U. Chem. Eur. J. 2002, 8, 4210-4215.

(19) (a) Furche, F.; Ahlrichs, R.; Wachsmann, C.; Weber, E.; Sobanski, A.; Vögtle, F.; Grimme, S. J. Am. Chem. Soc. 2000, 122, 1717-1724. (b) Autschbach, J.; Ziegler, T.; van Gisbergen, S. J. A.; Baerends, E. J. J. Chem. Phys. 2002, 116, 6930-6940. (c) Brown, A.; Kemp, C. M.; Mason, S. F. J. Chem. Soc. A 1971, 751-755. [16] a) M. K. Lakshman, W. Xiao, J. M. Sayer, A. M. Cheh, D. M. Jerina, J. Org. Chem. 1994, 59, 1755-1760; b) J. Gawroński, P. Grycz, M. Kwit, U. Rychlewska, Chem. Eur. J. 2002, 8, 4210-4215. 